U.S. GEOLOGICAL SURVEY CIRCULAR 1067

\title{
Program for Earthquake Hazards Assessment in the Pacific Northwest
}

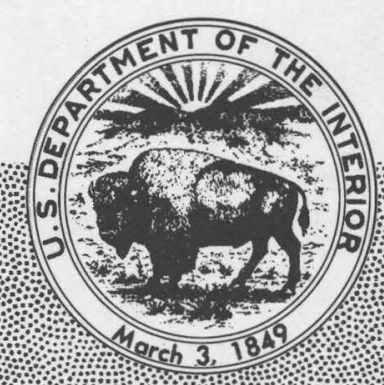


Instructions on ordering publications of the U.S. Geological Survey, along with prices of the last offerings, are given in the current-year issues of the monthly catalog "New Publications of the U.S. Geological Survey." Prices of available U.S. Geological Survey publications released prior to the current year are listed in the most recent annual "Price and Availability List." Publications that are listed in various U.S. Geological Survey catalogs (see back inside cover) but not listed in the most recent annual "Price and Availability List" are no longer available.

Prices of reports released to the open files are given in the listing "U.S. Geological Survey Open-File Reports," updated monthly, which is for sale in microfiche from the U.S. Geological Survey, Books and Open-File Reports Section, Federal Center, Box 25425, Denver, CO 80225 . Reports released through the NTIS may be obtained by writing to the National Technical Information Service, U.S. Department of Commerce, Springfield, VA 22161; please include NTIS report number with inquiry.

Order U.S. Geological Survey publications by mail or over the counter from the offices given below.

\section{BY MAIL}

\section{Books}

Professional Papers, Bulletins, Water-Supply Papers, Techniques of Water-Resources Investigations, Circulars, publications of general interest (such as leaflets, pamphlets, booklets), single copies of Earthquakes \& Volcanoes, Preliminary Determination of Epicenters, and some miscellaneous reports, including some of the foregoing series that have gone out of print at the Superintendent of Documents, are obtainable by mail from

\section{U.S. Geological Survey, Books and Open-File Reports Federal Center, Box 25425 Denver, CO 80225}

Subscriptions to periodicals (Earthquakes \& Volcanoes and Preliminary Determination of Epicenters) can be obtained ONLY from the

\section{Superintendent of Documents \\ Government Printing Office \\ Washington, D.C. 20402}

(Check or money order must be payable to Superintendent of Documents.)

\section{Maps}

For maps, address mail orders to

\section{U.S. Geological Survey, Map Distribution Federal Center, Box 25286 Denver, CO 80225}

Residents of Alaska may order maps from

\author{
Alaska Distribution Section, U.S. Geological Survey, \\ New Federal Building - Box 12 \\ 101 Twelfth Ave., Fairbanks, AK 99701
}

\section{OVER THE COUNTER}

\section{Books}

Books of the U.S. Geological Survey are available over the counter at the following Geological Survey Public Inquiries Offices, all of which are authorized agents of the Superintendent of Documents:

- WASHINGTON, D.C.--Main Interior Bldg., 2600 corridor, 18 th and C Sts., NW.

- DENVER, Colorado--Federal Bldg., Rm. 169, 1961 Stout St.

- LOS ANGELES, California--Federal Bldg., Rm. 7638, $300 \mathrm{~N}$. Los Angeles St.

- MENLO PARK, Californir --Bldg. 3 (Stop 533), Rm. 3128, 345 Middlefield Rd.

- RESTON, Virginia--503 National Center, Rm. 1C402, 12201 Sunrise Valley Dr.

- SALT LAKE CITY, Utah--Federal Bldg., Rm. 8105, 125 South State St.

- SAN FRANCISCO, California--Customhouse, Rm. 504, 555 Battery St.

- SPOKANE, Washington--U.S. Courthouse, Rm. 678, West 920 Riverside Ave.

- ANCHORAGE, Alaska--Rm. 101, 4230 University Dr.

- ANCHORAGE, Alaska--Federal Bldg, Rm. E-146, 701 C St.

\section{Maps}

Maps may be purchased over the counter at the U.S. Geological Survey offices where books are sold (all addresses in above list) and at the following Geological Survey offices:

- ROLLA, Missourl--1400 Independence Rd.

- DENVER, Colorado--Map Distribution, Bldg. 810, Federal Center

- FAIRBANKS, Alaska--New Federal Bldg., 101 Twelfth Ave. 
Program for Earthquake Hazards Assessment in the Pacific Northwest

By KAYE M. SHEDLOCK and CRAIG S. WEAVER 


\section{U.S. DEPARTMENT OF THE INTERIOR MANUEL LUJAN, JR., Secretary}

\section{U.S. GEOLOGICAL SURVEY}

Dallas L. Peck, Director

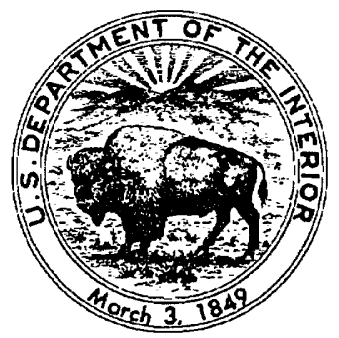

First printing, 1991.

Second printing, 1993.

Any use of trade, product, or firm names in this publication is for descriptive purposes only and does not imply endorsement by the U.S. Government.

For sale by the

Books and Open-File Reports Section

U.S. Geological Survey

Federal Center

Box 25425

Denver, CO 80225

Library of Congress Cataloging-in-Publication Data

Shedlock, Kaye $M$.

Program for earthquake hazards assessment in the Pacific Northwest / by

Kaye M. Shedlock and Craig S. Weaver.

p. cm.-(U.S. Geological Survey circular ; 1067)

Includes bibliographical references.

Supt. of Docs. no.: I 19.412:CIRC 1067

1. Earthquake hazard analysis-Northwest, Pacific. 2. National Earthquake Hazards Reduction Program (U.S.) I. Weaver, Craig S. II. Title. III. Series. QE535.2.N6S54 1991

$551.2^{\prime} 2^{\prime} 09795-\mathrm{dc} 20$

$91-20675$ 


\section{CONTENTS}

Summary $\mathbf{1}$
Introduction $\mathbf{1}$
Geologic and tectonic settings

Earthquake hazards and risk assessment in the Pacific Northwest

Earthquake sources $\quad 6$

Crustal earthquakes $\quad 6$

Intraplate earthquakes $\mathbf{1 1}$

Interplate earthquakes $\mathbf{1 1}$

Structure of the crust and lithosphere

12

Deformation record 14

Geodetics 15

Ground failure 17

Strong ground-motion and structural response $\quad \mathbf{1 8}$

Framework for NEHRP studies $\quad 20$

Necessary program components $\mathbf{2 0}$

Monitoring seismicity and deformation in the Pacific Northwest

Tectonic framework studies $\mathbf{2 2}$

Improve seismic hazard and risk assessments

Cooperative hazard mitigation studies 25

Relation to the USGS Earthquake Hazards Reduction Program

Conclusions 25

Acknowledgments 26

References cited $\mathbf{2 6}$

Appendix-Pacific Northwest Science Plan Workshop participants

\section{FIGURES}

1-6. Maps showing:

1. Boundaries and physiographic provinces of the Pacific Northwest region 2

2. Locations of earthquakes in the Pacific Northwest with magnitudes estimated to be greater than $6,1870-1990 \quad 4$

3. Distribution of crustal earthquake activity, 1980-1990 7

4. Distribution of earthquakes deeper than $30 \mathrm{~km} 7$

5. Distribution of Modified Mercalli Intensities, 1872 earthquake 8

6. Seismicity in eastern Washington, 1970-1987, magnitude 1.0 and larger 9

7. Diagram of inferred crustal structure, eastern Washington $\mathbf{1 0}$

8-10. Maps showing:

8. Major damaging earthquakes in Oregon and Washington 11

9. Distribution of Modified Mercalli Intensities, 1964 Prince William Sound, Alaska, earthquake 12

10. Contours of crustal thickness, Pacific Northwest 13

11. Photograph and map showing evidence for subsidence and areas of marsh stratigraphy studies 
12-14. Maps showing:

12. Average crustal strain accumulation along the Cascadia subduction zone 16

13. Locations of GPS strain networks along the Cascadia subduction zone 17

14. Extent of the Osceola debris flow

18

15. Photograph of ground-failure damage in Olympia, Washington, induced by the 1965 earthquake 19

16-19. Maps showing:

16. Regional seismic network stations in the Pacific Northwest

17. Strong-motion accelerometer stations operating in the Pacific Northwest

\section{1}

18. Proposed locations of crustal structure profiles

23

19. Areas of special hazards or special studies

24 


\title{
Program for Earthquake Hazards Assessment in the Pacific Northwest
}

\author{
By Kaye M. Shedlock and Craig S. Weaver
}

\section{Summary}

The Pacific Northwest (including the part of California north of Cape Mendocino, Oregon, Washington, and part of British Columbia) may be capable of producing a great subduction-zone earthquake of magnitude 8-9. While no earthquake of this size has historically occurred here, there is mounting geologic, geomorphologic, and geophysical evidence suggesting that such an occurrence is a strong possibility. Large crustal and intraplate earthquakes (magnitude $\cong 6-7$ ) have historically occurred in the Pacific Northwest and are expected to continue to occur. Furthermore, the level of instrumentally recorded seismicity, although not uniform across the region, is one of the highest in the United States.

Potential losses in the Pacific Northwest, as a result of either a great subduction-zone earthquake or crustal and (or) intraplate earthquakes near population centers, are expected to be large for a number of reasons. First, the population has grown considerably over the last few decades and continues to increase rapidly. Second, most buildings, bridges, lifelines, and transportation facilities were not designed or built to withstand large earthquakes. Third, the population centers (and, hence, the areas containing the highest concentrations of buildings) in the Pacific Northwest tend to be located in basins or in low-lying coastal areas-these are areas of poorly consolidated sedimentary rocks that will likely amplify ground motions or that are susceptible to local ground failure. A great subduction-zone earthquake in this area could cost about $\$ 8.6$ billion and result in the loss of hundreds of lives. A crustal or intraplate earthquake of magnitude 6-7 near Seattle could cause losses in the range of tens of millions of dollars (S.T. Algermissen, written commun., 1990).

Losses due to earthquakes can be reduced by means of effective mitigation measures, but these mitigation measures cannot be implemented without reliable characterization of earthquake hazards. The likely types, sizes, frequencies, locations, and effects of future earthquakes must be well understood. This program for earthquake hazard assessment in the Pacific Northwest is designed to address the necessary questions and to develop strategies needed to both characterize earthquake hazards and to quantify the associated risks.

Manuscript approved for publication March 21, 1991.

\section{INTRODUCTION}

The National Earthquake Hazards Reduction P"ogram (NEHRP) was authorized by the Earthquake Hazards Reduction Act of 1977 to provide information abo't both earthquake hazards and risk to concerned citizens, public officials, and planners in order to (1) minimize loss of life and property that can result from earthquakes and earthquake-related hazards, and (2) to minimize economic hardship and social disruption that can result from the occurrence of an earthquake and its related hazards.

As a participating agency in the NEHRP, tre U.S. Geological Survey (USGS) is charged with the leadership role in conducting fundamental research studies designed to delineate, evaluate, and document earthquake hazards in the United States. Thus, the USGS is the lead agency for studies of earthquake potential; earthquake prediction; earthquake information and data services; earthquake hazards and risk assessments; strong ground-motion data collection, dissemination, and estimation; and technical assistance in developing methods to implement loss-reduction measures. The NEHRP specifies seismically active geographic regions within the United States for program emphasis. This document describes the current plans and priorities for future research of this USGS program in one of the regions of current emphasis: the Pacific Northwest.

Within the context of the current NEHRP program, the Pacific Northwest is understood to include northern California, Oregon, and Washington, with particular emphasis on the subduction-zone system that reaches from Cape Mendocino in northern California northward along the Pacific coast to northern Vancouver Island (fig. 1). Our study area includes the Cascade Range and adjacent regions of the backarc provinces, particularly the Pasco basin and adjacent parts of the Columbia Plateau and southwestern British Columbia (fig. 1).

The Pacific Northwest is the only location in the United States where crustal and lithospheric evolution may be traced from an active mid-ocean ridge to a stable continental platform in a distance of only 1,200 km (fig. 1). Thus, the USGS program must include scientific 


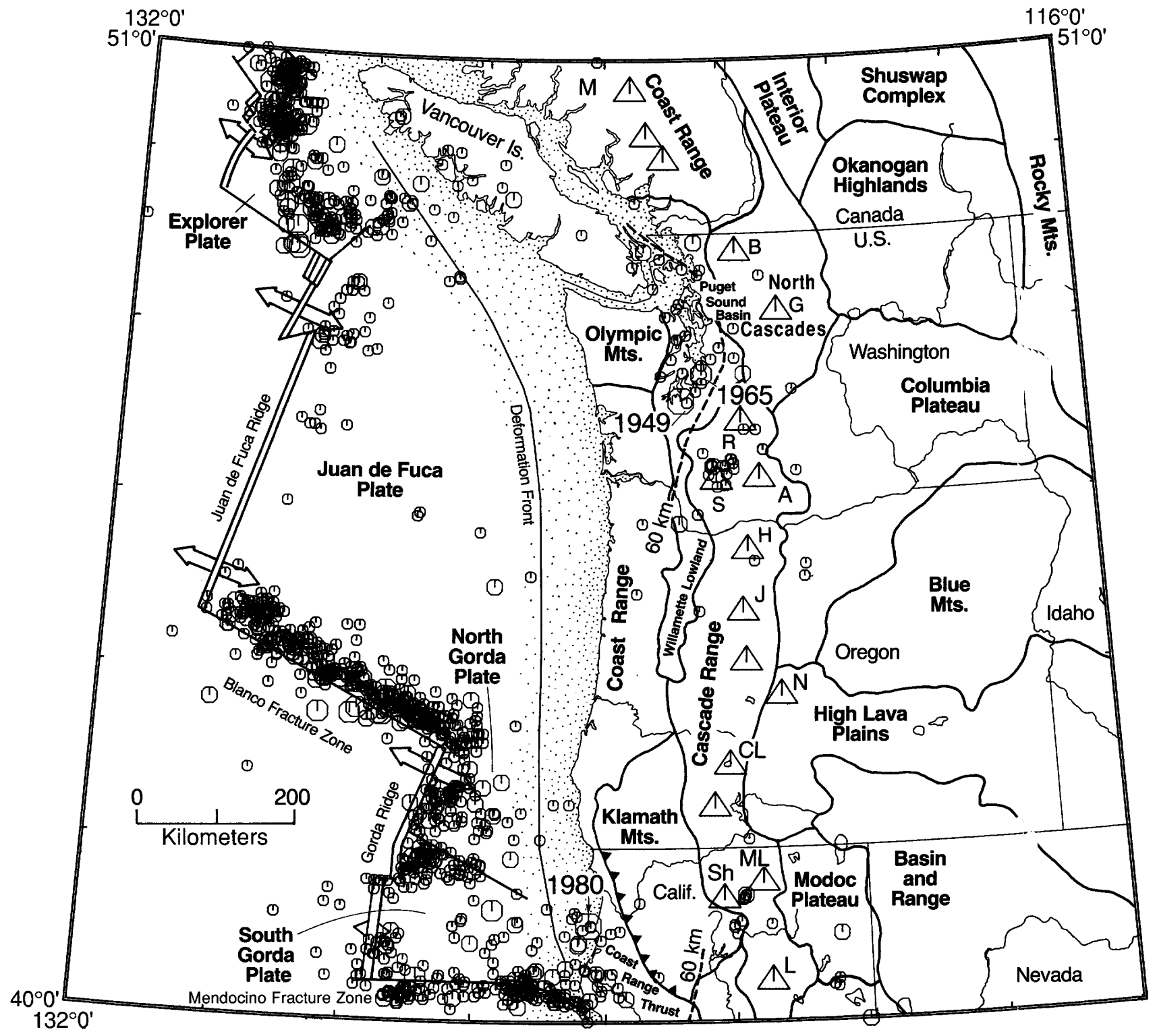

Figure 1. Map showing plate boundaries and physiographic provinces of the Pacific Northwest region. Octagons denote epicenters of earthquakes of magnitude 4 or larger that are listed in the National Oceanic and Atmospheric Administration (NOAA) catalog through 1985. Location of the 1949 south Puget Sound earthquake, the largest instrumentally recorded event in Washington or Oregon, is indicated by the largest octagon and is labeled "1949." Open triangles represent Quaternary stratovolcanoes: M, Meagher Mountain; B, Mount Baker; G, Glacier Peak; R, Mount Rainier; S, Mount St. He'ens; A, Mount Adams; H, Mount Hood; J, Mount Jefferson; N, Newberry Volcano; ML, Medicine Lake Volcano; Sh, Mount Shasta; L, Lassen Peak; CL, Crater Lake. From Ludwin and others (in press).

investigations covering a broad spectrum of earthquake hazards and a wide range of tectonic conditions. Within the last decade, the population living in the Pacific Northwest has experienced a number of significant geologic hazards: Mount St. Helens continues an eruptive sequence (accompanied by seismic activity) that began in 1980; the largest crustal earthquake in Oregon or Washington since 1937 (magnitude 5.5) occurred north of Mount St. Helens in 1981; and the largest (possibly earthquake-related) landslide on Mount Rainier since 1963, involving about 1-2 million cubic meters, occurred during the summer of 1989. The possibilities of large to great earthquakes in this region are most important in USGS geologic hazard studies. Some investigators (e.g., Heaton and Hartzell, 1986) have suggested that an earthquake as large as magnitu te 9 (similar to the 1960 Chilean or 1964 Alaskan events) corld occur along the coasts of northern California, Oregon, Washington, and southern British Columbia. The staggering size of the source regions for such great earthquakes (fig. 1) requires that our hazard assessments be on an equall; large scale. 
Because the USGS recognizes the implications to society should it be proven that the Pacific Northwest is capable of generating great earthquakes, it is contributing to a comprehensive earthquake hazards reduction program that, by necessity, has a heavy emphasis on earthquake hazards assessments. Such a program needs to encourage major scientific advances in understanding the nature of the entire subduction margin and forearc region and should offer the means to coordinate these new perspectives into hazard studies throughout the region. By the end of the program outlined here, scientists from the USGS, other government agencies, and universities will have collected and analyzed a broad suite of data that is an essential component in our effort to assess potential earthquake hazards associated with the subduction interface.

Within this large geographic area, most regional-scale USGS/NEHRP studies will relate primarily to sources of and potential for earthquakes - detailed studies of hazards and associated risks will be confined largely to the urban areas surrounding Puget Sound, and in the Pasco basin, the Willamette Lowland, and coastal areas. We include British Columbia in the study area both because the subduction zone continues northward to central Vancouver Island and because we believe that our program should take advantage of joint research opportunities with the Geological Survey of Canada.

Because of the complex geologic setting of the Pacific Northwest, scientific objectives central to providing the tectonic framework necessary for a rational assessment of earthquake hazards must be broadly stated. The central goal of the proposed program is to answer these questions:

- Can the Cascadia subduction zone produce great thrust-zone earthquakes?

- What are the expected distributions; source characteristics; and effects of shallow, crustal earthquakes in the Pacific Northwest?

- What are the principal seismic hazards in the Pacific Northwest?

- What combination of short-term (i.e., relating to the repeat of a known earthquake) and long-term (i.e., relating to a large, crustal earthquake in an urban area or a thrust-zone earthquake) risk-reduction measures should be pursued in the Pacific Northwest?

\section{GEOLOGIC AND TECTONIC SETTINGS}

Washington, Oregon, and northern California have features typical of convergent boundaries in other parts of the world. Offshore, on the continental shelf, deformed Quaternary sediments are found where converging plates meet (Barnard, 1978). A convergence rate of $4-4.5 \mathrm{~cm} / \mathrm{yr}$ between these two plates and a convergence direction of approximately N. $50^{\circ}$ E. have been estimated by Riddihough $(1977,1984)$. The regional free-air and Bouguer gravity anomalies show a pattern common in subduction zones: an elongated gravity low along the toe of the continental slope and a gravity high inland over the coastal mountains. An active andesitic volcanic arc, dating from the middle Miocene, covers the area from northern California to southern British Columbia and is consistent w:th the presence of a subducting plate at a depth of about $100 \mathrm{~km}$. Beneath western Washington, a zone of earthquakes at depths of $35-80 \mathrm{~km}$, distinct from crustal earthquakes, inclines down to the east from the coast (Crosson, 1983); this has been interpreted as an intraplate Benioff zone (Crosson, 1983; Taber and Smith, 1985). Similarly, a dipping Benioff zone has been defined beneath northern California (Cockerham, 1984; Walter, 1986). Most of the larger earthquakes in Oregon and Washington since the mid-1800's have probably occurred within this deep zone (Rogers, 1983a); however, in northern California, the largest historical events have been located offshore, in the Gorda plate.

Onshore, the surficial geology of northern California, Oregon, and Washington is complex, reflecting in part long-term convergent tectonics and plate margin accretion. The Klamath Mountains, North Cascades, and Blue Mountain provinces (fig. 1) are largely pre-Cenozoic terranes that include folded and metamorphosed complexes of continental basements and sediments (Misch, 1966). Volcanism in the Cenozoic Era was extensive and voluminous. The Western Cascades, High Cascades, and Columbia Plateau provinces experienced repeated eruptions of basaltic and (or) andesitic lavas. During the Quaternary Period, volcanism has been more limited in extent. South of the latitude of Mount Adams, Quaternary volcanic rocks are exposed almost continuously in the High Cascedes in Oregon and northern California. North of Mount Adams, Quaternary volcanism has been confined to the large stratovolcanoes of the Cascade Range. The Olympic Mo'ıntains and the Coast Range of Washington and Oregon consist mainly of Tertiary oceanic sediments and basaltic volcanics (Cady, 1975). These rocks appear to have been accreted to the continent in the subduction process (Tabor, 1972). The Olympic Mountains have been interpreted as oceanic basement obducted onto the continental margin (Snavely, 1988). Paleomagnetic data from the Coast Range have been used to infer a significant rotation for this province compared to inland provinces (Magill and others 1981, 1982; Beck and Engebretson, 1982). The Puget-Willamette Lowland is an extensive depression covered by thick sedimentary sequences eroded from the Olympic Mountains, the Coast Range, and the Cascade Range during Miocene uplift (Tabor, 1972; Cady, 1975). 
The distribution of Pacific Northwest earthquakes having magnitudes greater than 4.0 for the period 1960-1985 (fig. 1) only weakly reflects the convergent framework. Most of the events were located offshore: major activity was located primarily at the transform fault boundaries such as the Blanco fracture zone. Although there was moderate activity near the Gorda and Explorer ridges, the major ridge in the region (the Juan de Fuca) is seismically quiet. Likewise, the subduction zone and continental margin of Washington and Oregon are seismically quiet compared to the offshore transform faults. Very few earthquakes have occurred in Oregon: this fact agrees with an early observation by Montessus de Ballore (1906), who noted an absence of damaging earthquakes between Portland, Oregon, and Crescent City, California. The sparse distribution of earthquakes onshore in Washington and Oregon contrasts markedly with the distribution of seismicity reported in most active subduction zones where numerous earthquakes occur at the interface between the two plates, within the subducting plate, and within the overriding plate (Uyeda and Kanamori, 1979). For the Oregon-Washington portion of the Cascadia subduction zone, no subduction or thrust earthquakes have been identified along the plate interface at any magnitude level; a few small-magnitude thrust earthquakes that might have occurred along the plate interface have tentatively been identified offshore of northern California (McPherson, 1989).

One of the significant problems in assessing the earthquake hazards of the Pacific Northwest is the discordance between the historical earthquake record and the record available from modern seismic instrumentation (dating from about 1950). The historical record is essential because, in Washington and Oregon, the only earthquake greater than magnitude 6 since the World Wide Standard Seismic Network began recording in 1962 is the 1965 event near Seattle. Since 1962, all events greater than magnitude 6 in California north of Cape Mendocino have been located offshore in the Gorda plate. Thus, one objective of the earthquake hazards assessment program must be to place historical, larger magnitude earthquakes within the regional tectonic framework. This task is made more difficult in western Oregon and Washington by the lack of known faults with late Holocene surface offsets.

Since 1870 , earthquakes estimated to be larger than magnitude 6 are almost totally restricted to northwestern Washington and northwestern California, where most of the larger events are located offshore (fig. 2). The 1872 North Cascades earthquake is generally considered to be the largest earthquake known in the Pacific Northwest (Milne, 1956): it had an estimated magnitude of 7.4 (Malone and Bor, 1979). This earthquake was felt over an area of more than $1,010,000 \mathrm{~km}^{2}$, including Washington, central to northern Oregon, northern Idaho, western Montana, and southern British Columbia. The earthquake was followed by

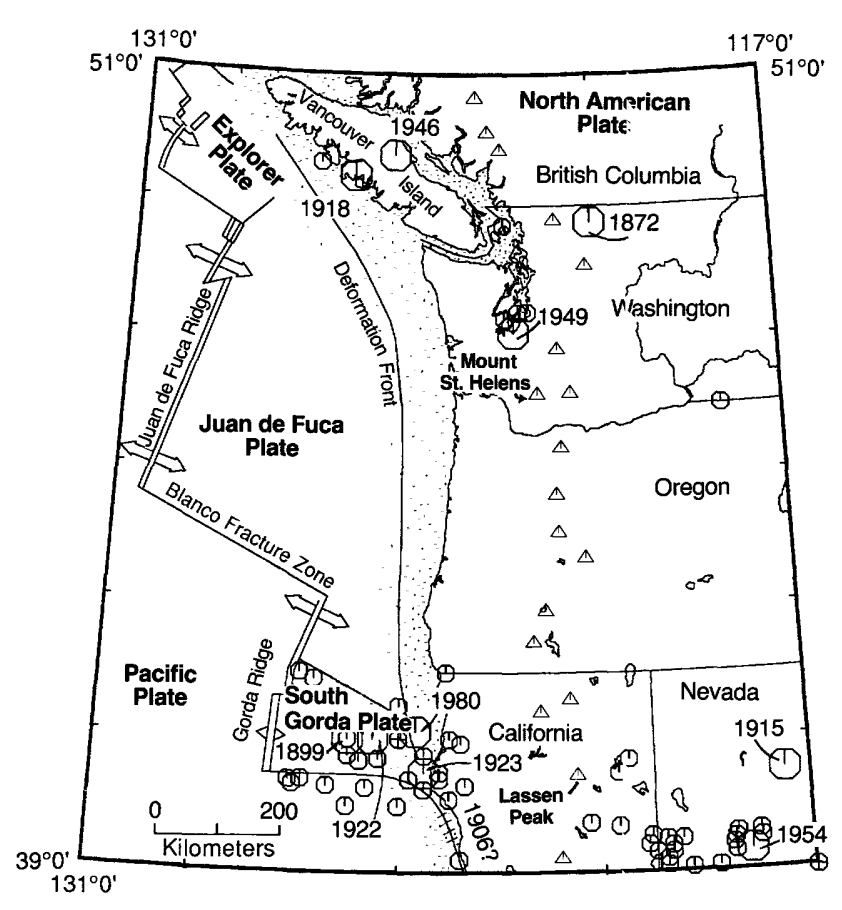

Figure 2. Map showing locations of earthruakes in the Pacific Northwest with magnitudes estimated to be greater than 6 for the years 1870-1990 (octagons). Open triangles represent Quaternary stratovolcanoes. Except for the Cape Mendocino area, offshore earthquakes clearly related to the ridge system have not been shown. Earthquakes greater than magnitude 7 are labeled with year of occurrence and are discussed in the text. Earthquake magnitudes and locations for northern California from Ellsworth (1990); Vancouver Island data from Rogers and Hasegawa (1978) and frcm Cassidy and others (1988); Oregon and Washington data from Ludwin and others (in press).

an extensive aftershock sequence (Milne, 1956). Study of damage reports suggests that the maximum intensity (on the Modified Mercalli scale) exceeded VII and may have been as high as IX (Milne, 1956). Both the location and depth of the North Cascades earthquake are subjects of controversy. The location shown in figure 2 was determined by Malone and Bor (1979) based on the intensity pattern: these authors also summarize other suggested locations of the event. Hopper and others (1982) have suggested a shallow depth based upon intensity contours and the extensive aftershock sequence. All instrumentally located eartrquakes (since 1970) near the epicenter proposed by Mclone and Bor (1979) are shallower than $25 \mathrm{~km}$. The depth of this earthquake is, therefore, unresolved: a shallow earthquake of magnitude 7.4 should have a rupture area large enough so that primary surface faulting would be evident-none has been noted (Shannon and Wilson, Inc., 1977).

An earthquake estimated to have a magnitude of at least 6.75 (Toppozada and others, 1981) occurred in 1873 near the Oregon-California border (fig. 2). The earthquake was felt from near Portland, Oregon, to Sacramento, California, but was felt with intensity VIII only in a small 
area north of Crescent City, California (Toppozada and others, 1981). There is no mention of felt aftershocks accompanying the mainshock in newspaper accounts of the event. This observation suggests that either the event was sufficiently far offshore so that aftershocks were not felt or that it was deep, possibly within the subducting Gorda plate.

The 1936 Milton-Freewater earthquake is the largest known event in the eastern Washington region. Maximum intensity was reported as VII (Coffman and others, 1982), and the surface wave magnitude has been calculated to be 5.75 (Gutenberg and Richter, 1954); the magnitude estimated from felt area has been calculated to be 6.4 by Noson and others (1988). Because numerous aftershocks were felt in 1936 and because all earthquakes in eastern Washington located since 1970 are in the crust, the 1936 event is also assumed to be crustal.

Between 1939 and 1965, four earthquakes (in 1939, 1946,1949 , and 1965) greater than magnitude 6 occurred in the southern Puget Sound basin (fig. 2; Rogers, 1983b). The 1949 (magnitude $=7.1$ ) and the 1965 (magnitude $=6.5$ ) earthquakes caused significant damage in the Puget Sound region (Murphy and Ulrich, 1951; Nuttli, 1952; Algermissen and others, 1965) and had instrumentally determined hypocentral depths of $54 \mathrm{~km}$ and $60 \mathrm{~km}$, respectively (Algermissen and others, 1965; Baker and Langston, 1987). No aftershocks were felt or recorded after the 1949 earthquake (instrumentation available at the time would have detected events larger than magnitude 4.5). Similarly, following the 1965 earthquake, no aftershocks were felt, and an examination of seismograms recorded on stations operating within the region failed to identify any aftershocks greater than magnitude 2.5 .

Moderate earthquakes off the northern California coast have been frequent during the last 120 years (fig. 2), but damage from these events has been of the non-structural type. The largest offshore event (magnitude 7.3) occurred in 1923, and shaking damaged a number of chimneys in small towns north of Cape Mendocino (Toppozada and others, 1981; Ellsworth, 1990). In 1980, a magnitude 7.0 event occurred within the Gorda plate, just west of the deformation front (fig. 2) but did little damage to structures. The most damaging earthquake in northwestern California to date is the 1954 Eureka event (fig. 2). This event was estimated to be of magnitude 6.5 ; one person was killed during this earthquake, and there was considerable nonstructural damage (Ellsworth, 1990).

At the northern end of the Juan de Fuca plate, there is a concentration of larger magnitude events across central Vancouver Island (fig. 1). This area has been subjected to two earthquakes greater than magnitude 7 : an event estimated to be of magnitude 7.2 in 1918 and a second event of magnitude 7.2 in 1946; in addition, there was an event of about magnitude 6 in 1957. Because central Vancouver Island is lightly populated and because the hypocentral depths of the 1918 and 1946 events have been estimated to be about 20 and $30 \mathrm{~km}$, respectively, actual damage from these earthquakes was very slight. Nevertheless, because these events occurred within the crust of the North American plate (Cassidy and others, 1988), they raise serious questions as to the possibility of similar eartl juakes occurring in heavily populated urban areas of the Pacific Northwest.

Actual losses from earthquakes occurring in the Pacific Northwest were greatest from the 1949 ard 1965 events. Eight people were killed in the 1949 earthquake (Ulrich, 1949) and six died in the 1965 earthquake (Algermissen and others, 1965). In terms of 1984 dollars, $\$ 150$ million in damage occurred in 1949; the 1965 event produced an estimated $\$ 50$ million in damage (Noson and others, 1988). The effects of the 1949 and 1965 earthquakes are currently used as the basis for engineering design, emergency response planning, and damage and loss estimates in the Puget Sound region (Hopper and others, 1975). Since the 1975 report was issued, the population of the Puget Sound region has increased by more than 600,000 , and many new structures have been built. More importantly, the 1975 study considered only the effects of deep earthquakes and did not consider the effect of either a shallow, crustal earthquake (like the 1872 event) or the possible effects of a great earthquake on the megathrust. Thus, there is wide agreement in the scientific community, in engineering groups, in political bodies, and among residents of the region that a updated discussion of the sources, the hazards posed by these sources, and estimates of earthquake losses is urgently needed in the Pacific Northwest.

\section{EARTHQUAKE HAZARDS AND RISK ASSESSMENT IN THE PACIFIC NORTHWEST}

The first step in providing an assessment of earthquake hazards and risk within a region requires that the nature and distribution of earthquake sources be und rstood. During the past 10 years of the NEHRP program, much of the effort in the Pacific Northwest has focused on definition of the nature of the hazards rather than on methods of immediately reducing risk. In this regard, it is interesting to take two measures of our enhanced understanding of the earthquake hazards. First, Hopper and others (1975) suggested that the Juan de Fuca plate may be attached to the North American plate, thereby making it unlikely th at great earthquakes could occur on the interface between the two plates. Fifteen years later, most earth scientists acknowledge the potential of thrust earthquakes on this interface at least as large as magnitude 8.0 , and many scientists argue that earthquakes greater than magnitude 9.0 may occur here. Second, Perkins and others (1980) issued a revised estimate of maximum horizontal ground-acceleration for Oregon and Washington in which it was necessary to regionalize the 
maximum expected earthquake: in the southwestern Washington Cascade Range, near Mount St. Helens, the magnitude of the estimated maximum earthquake used in the analysis was 5.1. By 1985, the St. Helens seismic zone had been identified, and a maximum magnitude event of 6.8 was adopted for engineering-design purposes for several structures built to help control the level of debris-dammed lakes that formed in the aftermath of the May 18, 1980, eruption.

After reviewing the accomplishments of the NEHRP in the Pacific Northwest, we recognize that the region is not yet in the position of grappling with measures to reduce the effects of great earthquakes along the coast; however, we are taking the first steps toward an understanding of the physical processes that cause these earthquakes. We are also not yet at the point of issuing probabilities for the next major earthquake. These two items (the lack of a policy for risk reduction and the lack of probability estimates) reflect a difference between the Pacific Northwest and California. In the Pacific Northwest, only a few earthquakes greater than magnitude 6 have occurred (fig. 2). Exposed faults that have late Holocene offsets are rare, and the instrumental record of seismicity is not in complete agreement with either the distribution of historical earthquakes or mapped evidence of faulting. Thus, in this region, we are not yet at the point of making intermediate-term forecasts concerning possibly damaging earthquake activity. Nevertheless, over the past decade, much progress has been made in the Pacific Northwest toward resolving many of the uncertainties of earthquake hazards. In turn, as our ability to quantify hazards has improved, we are beginning to see added emphasis on a better understanding of the risks posed.

The state of knowledge of the seismotectonics of the Pacific Northwest contrasts sharply with the current focus in California on issuing probabilities of future seismic activity. Central and southern California are dominated by strike-slip tectonics, and three independent data sets are available to integrate into probability estimates: first, there is a historical record that is liberally sprinkled with magnitude 6 and greater earthquakes; in some cases there are repeat earthquakes available in the historical record. Second, there are geological data for surface faults that allow for independent assessment of previous large earthquakes. Third, modern, instrumental seismicity shows a pattern consistent with both the geological record and historical earthquake data - this has allowed all three data sets to be unified under a comprehensive plate tectonic framework. Thus, in California, the USGS and other groups are in the position of beginning to estimate intermediate-term probabilities (10 years to a few decades) for the occurrence of large earthquakes along major fault systems (U.S. Geological Survey, 1988, 1990).

The estimation of probabilities for future earthquake occurrence is but one of many necessary steps that are part of regional risk-assessment and mitigation programs. Clear components of risk assessment include careful mapping of local soil and near-surface bedrock conditions and estimating how local sites will be affected by strong ground shaking. The design of mitigation programs relies directly on the ability of the earth sciences community to reliably communicate a clear statement of earthquake hazards to the general public. However, the final step (actual implementation of revised building codes, land-use zoning changes, building retrofitting, etc.) will likely only be achieved if the earthquake hazards program has been successful in developing the scientific case sc that political decisions will be made that will help to mitigate the effects of future earthquakes. Ultimately, tradeoffs will occur in the political arena between risk-reduction measures that are tailored for the largest conceivable earthquake a region may face and actions designed to prevent losses from perhaps more frequent, smaller earthquakes.

In the remainder of this section, w's provide a commentary on important results from the last 10 years and on some of the outstanding problems and opprrtunities that must be faced over the next 10 years.

\section{Earthquake Sources}

There are three distinct sources of earth quakes in the Pacific Northwest: (1) crustal earthquakes that occur within the overriding North American plate, (2) int"aplate earthquakes that occur within the subducting Juan de Fuca and Gorda plates, and (3) interplate earthqua'es that are expected to occur at the interface between the Juan de Fuca (and Gorda) plate and the North American plate (subduction or thrust events). West of the Cascade arc, the distribution of earthquake-source-type reflects a combination of factors: the geometry of the subducting Juan de Fuca and Gorda plates; crustal structure within the over:iding North American plate; and tectonic interactions among the North American, Pacific, and Juan de Fuca plates. East of the Cascades, it is likely that earthquake distribution primarily reflects the tectonics and structure of only the North American plate.

There are common questions for ea:h particular source region: how large might earthquakes be, where might they occur, how often do they occur, and what are the expected ground responses from each source type? Beyond these common questions, there is a wide range of questions appropriate for each source type. Most of these questions have yet to be addressed in any systematic way.

\section{Crustal Earthquakes}

The distribution of crustal earthquakes is not uniform across the Pacific Northwest (figs. 3 and 4). Weaver and others (1990) used sharp changes in seismicity to divide the Cascade Range and adjacent areas into four segments. In the 


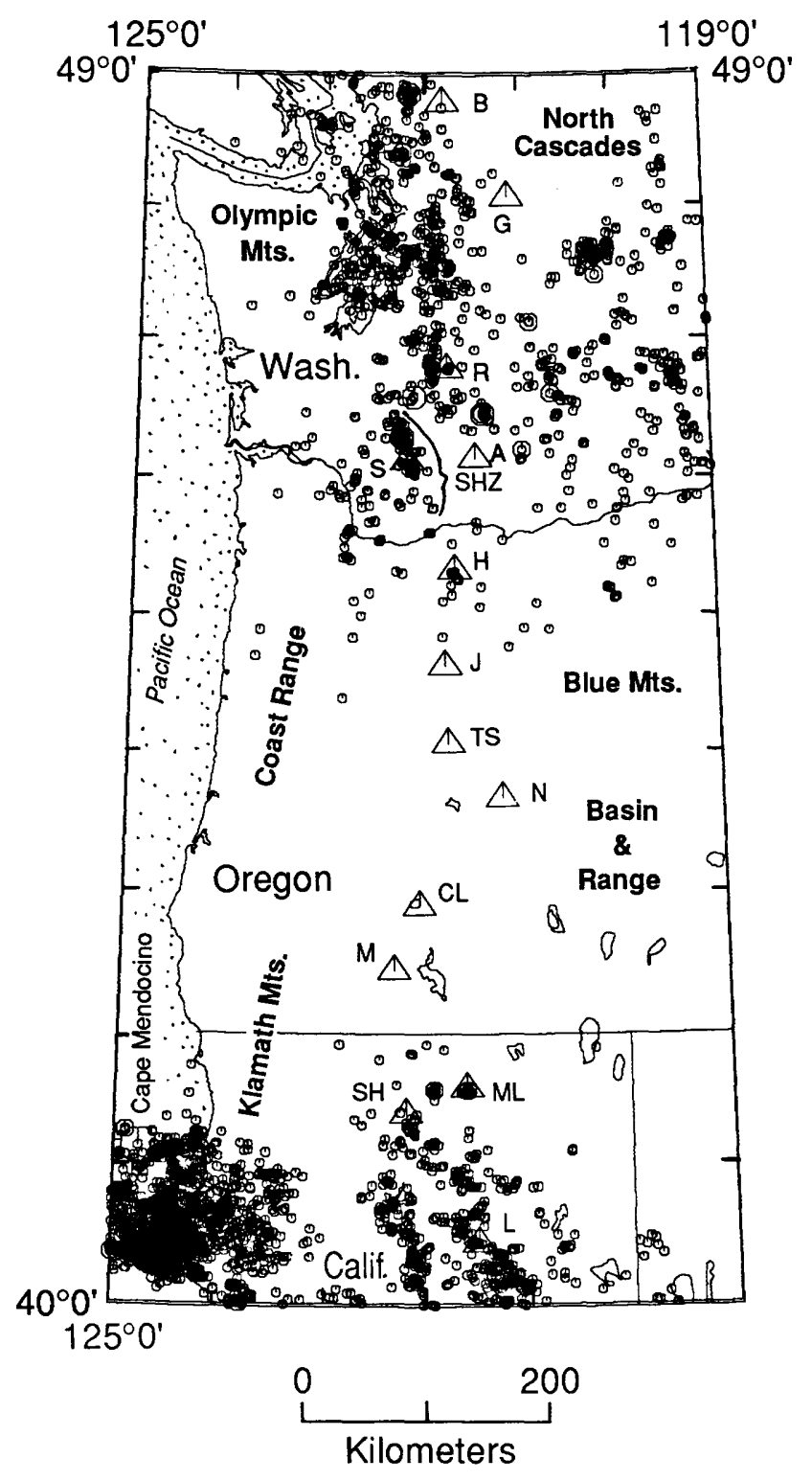

Figure 3. Map showing distribution of crustal earthquake activity, 1980-1990. Earthquakes shown are less than $30 \mathrm{~km}$ deep; location errors estimated to be less than $5 \mathrm{~km}$; rootmean-square error (RMS) less than 0.35 seconds; more than 6 stations reporting. $\mathrm{SHZ}$, St. Helens zone. Open triangles represent Quaternary stratovolcanoes: $M$, Meagher Mountain; B, Mount Baker; G, Glacier Peak; R, Mount Rainier; S, Mount St. Helens; A, Mount Adams; H, Mount Hood; J, Mount Jefferson; N, Newberry Volcano; ML, Medicine Lake Volcano; SH, Mount Shasta; L, Lassen Peak; TS, Three Sisters; CL, Crater Lake. From Weaver and others (1990).

first segment, nearly all of the well-located crustal earthquakes are confined to the region between the eastern Olympic Mountains and the western edge of the North Cascades (fig. 3); there are few events near Quaternary stratovolcanoes. The second segment defined by Weaver and others (1990), from Mount Rainier to Mount Hood, is the most seismically active segment. In southern

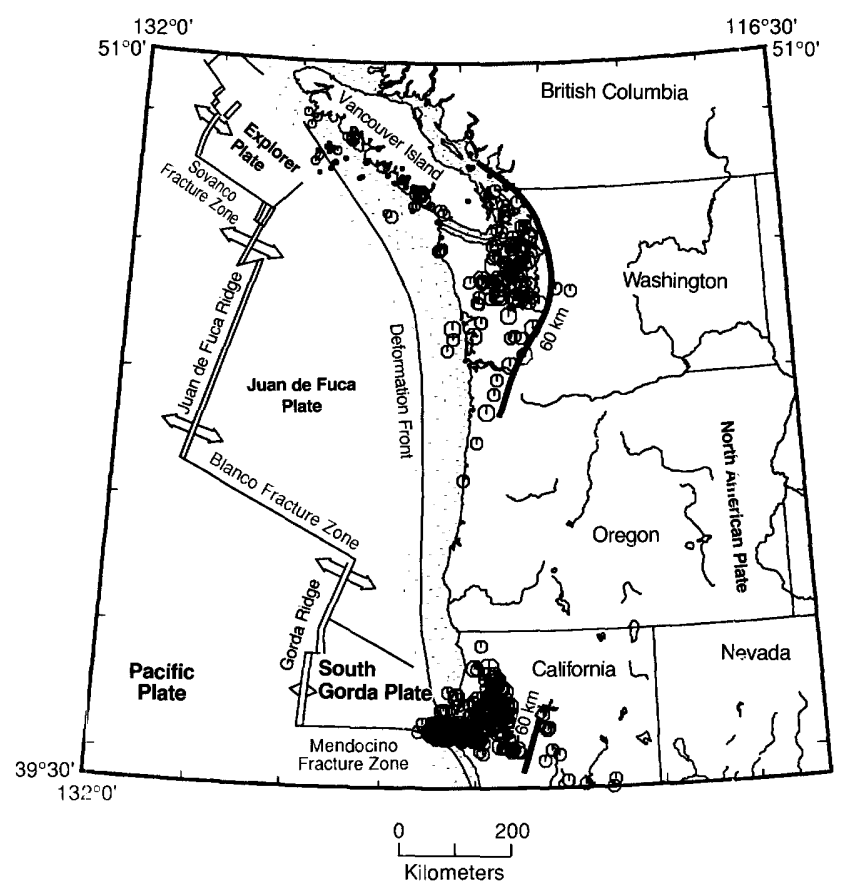

Figure 4. Map showing distribution of earthquakes deeper than $30 \mathrm{~km}$. Location errors estimated to be less than $5 \mathrm{~km}$; root-mean-square error (RMS) less than 0.35 seconds; more than 6 stations reporting. The $60-\mathrm{km}$ line shows the approximate easternmost extent of earthquake distribution at this depth. Although most of these earthquakes are intraplate earthquakes occurring within the Juan de Fuca plate, there are a few crustal earthquakes that occur at depths between 30 and $35 \mathrm{~km}$ below central Puget Sound.

Washington, the St. Helens zone (SHZ) is prominent within this segment. Although there is an absence of activity east of the SHZ, seismicity continues in a broad zone from the area immediately west of the SHZ into southeastern Washington (fig. 3). The third segment, from south of Mount Hood to just north of Mount Shasta, is seismically very quiet (fig. 3). Although this entire segment has not been monitored continuously, very few earthquakes were observed during the two years (1980-1982) of continuous operation of a 32-station network in the Cascade Range or since stations were reinstalled in the Cascade Range of central Oregon in 1987 (Ludwin and others, in press). There is a marked increase in earthquake activity in the fourth segment (betw'een Mount Shasta and Lassen Peak) and also along the northern California coast (fig. 3). At the present time, we do not understand why earthquakes are distributed in this pattern, even though the answer to this question is fundamental to our understanding of earthquake hazards in the Pacific Northwest.

Intensity patterns associated with the 1872 North Cascades earthquake (fig. 5), an extensive aftershock sequence, and the shallow depths of all earthquakes instrumentally recorded near the 1872 epicenter provide evidence for a shallow hypocenter for the 1872 event (Milne, 1956; Hopper and others, 1982), although no 


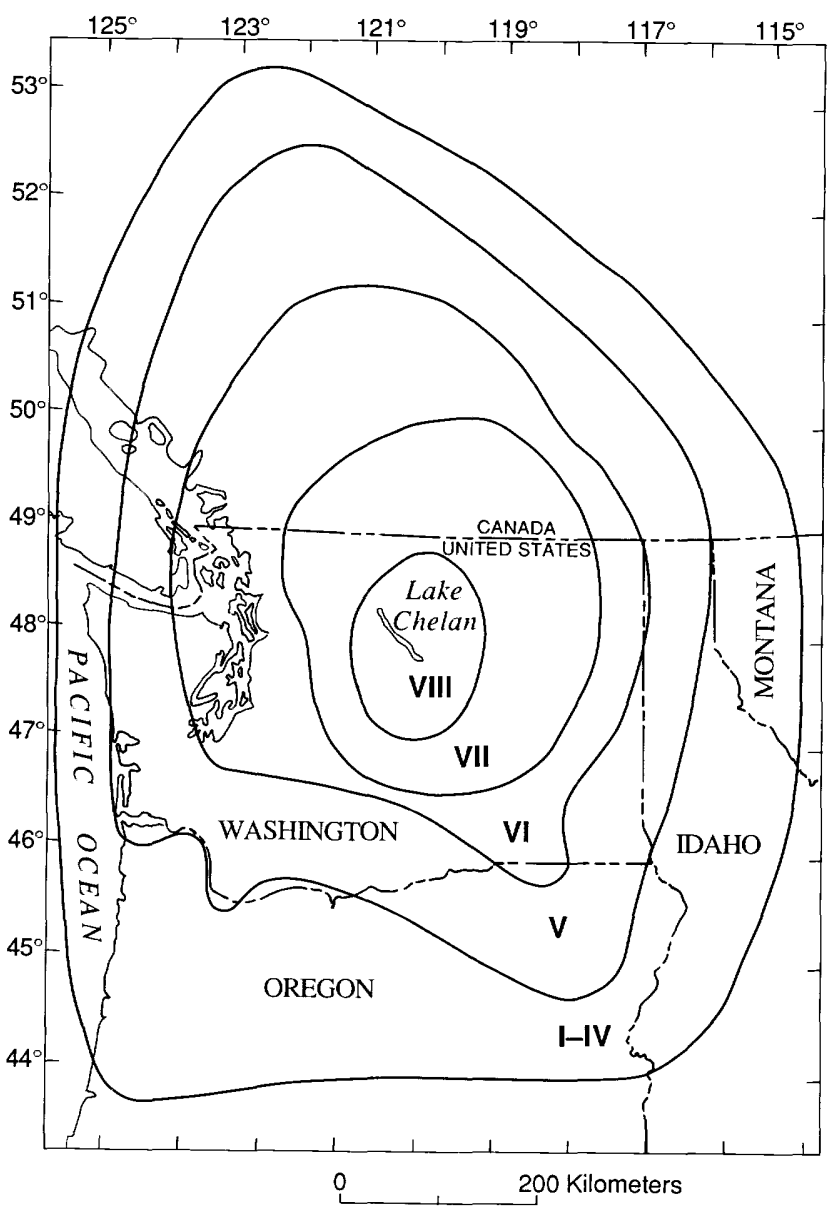

Figure 5. Map showing Modified Mercalli Intensity (MMI) plot of the 1872 earthquake. Based on this intensity pattern, researchers have inferred that the epicenter of the 1872 earthquake was located in the vicinity of Lake Chelan. Intensity VIII corresponds to structural damage (cracked walls, downed chimneys). Intensity VI (which would include all of the urban areas along Puget Sound) corresponds to shaking severe enough to cause items to fall from shelves. Modified from unpublished figure prepared by M.G. Hopper.

evidence of surface faulting has been noted (Shannon and Wilson, Inc., 1977). Two earthquakes of magnitude 7 or greater have occurred during this century (in 1918 and 1946) in central Vancouver Island. The existence of these events, which were most likely crustal, raises the issue of how much of Oregon, Washington, and northern California could be involved in such large, crustal events. Current crustal seismicity in the Puget Sound basin does not occur along linear fault zones but is distributed throughout the crust (fig. 3). Mapped Quaternary faulting in the basin is sparse (Gower and others, 1985), although newly collected shallow reflection data may support the interpretation of shallow Quaternary faulting within Puget Sound (Harding and others, 1988). Geologic mapping provides evidence of abrupt uplift of marine terraces at two locations within the basin: Restoration Point ( $5 \mathrm{~km}$ west of Seattle) and Belfair (35 km southwest of Restoration Point). These uplifts may be due to one or more earthquakes (Bucknam and Barnhard, 1989). These authors also state that "No comparable coseismic deformation has been observed historically in the region despite the occurrence of earthquakes as large as magnitude 7.2 (1949), suggesting the sudden uplift was produced by an earthquake source and mech`nism greatly different from any observed to date" (Bucknam and Barnard, 1989, p. 1,332). The 1949 earthquake wa: $54 \mathrm{~km}$ deep; it was not, therefore, a shallow, crustal earthquake. The available record of seismicity in the Puget Sound basin is usually interpreted to suggest that the expected maximum magnitude crustal earthquake is less than that expected in either southwestern or southeastern Washington (Ludwin and others, in press). The recent discover:' of uplifted terraces of Holocene age by Bucknam and Barnhard (1989) raises serious doubts about these other interpretations.

An important advance in understanding the hazards posed by crustal earthquakes has been the result of a series of studies along the St. Helens zone, a 130-km-long zone of moderate-magnitude earthquakes that strikes north-northwest through Mount St. Helens. The SHZ is a right-lateral strike-slip zone: nearly all of the focal mechanisms calculated to date have had nearly pure strike-slip solutions (Ludwin and others, in press). Although the largest known earthquake in the SHZ had a magnitude 5.5 , work by the USGS, the Army Corps of Engineers, and the State of Oregon Department of Geology and Mineral Industries all concluded that a much larger event (magnitude 6.2-6.8) could occur along the SHZ (Grant and Weaver, in press). This assessment of the SHZ has clear implications for the Portland area, where recent study of the seismicity has concluded that there may be a series of en echelon fault zones southwest of the SHZ (Yelin and Patton, 1991). The Portland Hills fault, a few $\mathrm{km}$ west of downtown Portland (Balsillie and Benson, 1971) is viewed as one of these zones. Because Portland has a history of moderatemagnitude earthquakes (approximately magritude 5 and above), it is clear that the area between the SHZ and the Portland Hills fault zone requires continued, close seismic monitoring to test this hypothesis.

One of the major issues for which virtually no work has yet been done is the relation between crustal structure and the distribution of crustal earthquakes. Generally, the crustal structure in Oregon and Washington is poorly known because there are few high-quality reversed refraction profiles of the region. However, a crustal refrcction profile across the Columbia Plateau through the Pasco basin coincides with an area of relatively high backarc crustal seismicity-this allows a comparison between the details of crustal structure and the distribution of seismicity. This refraction line (C-C', fig. 6) crossed a series of east-west striking thrust faults at acute angles and passec through the center of the Pasco basin where deposits of th $\%$ Columbia River Basalt Group are thought to be thickest. 


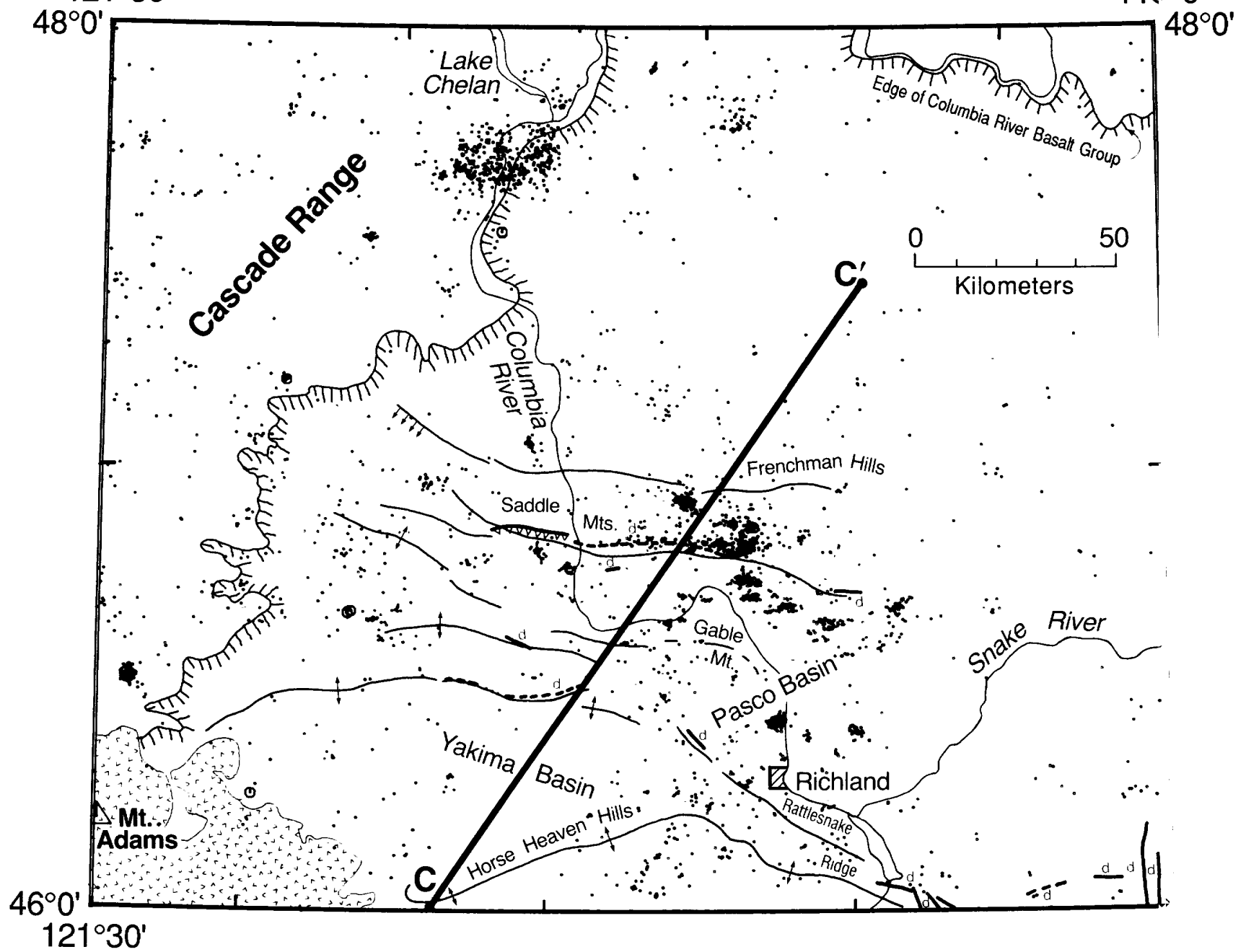

Figure 6. Map showing seismicity in eastern Washington, 1970-1987, magnitude 1.0 and larger. Earthquake magnitudes are shown by two symbol sizes: events less than magnitude 4 denoted by dots; events greater than magnitude 4 denoted by open circles. Heavy lines are mapped faults of post-Miocene age (d, downthrown side); light lines are axes of major anticlines. The western margin of the Columbia River Basalt Group is indicated by hachures; Quaternary volcanics near Mount Adams are

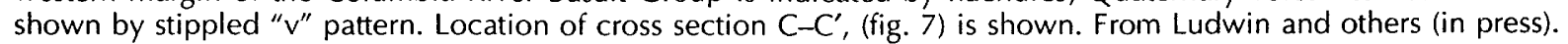

The crustal structure, interpreted by Catchings and Mooney (1988) along line C- $\mathrm{C}^{\prime}$ on figure 7, contains four features of interest with respect to earthquake distribution: (1) a series of alternating layers of high and low P-wave velocity (5.85 and $5.3 \mathrm{~km} / \mathrm{s}$, respectively) comprises the Columbia River Basalt Group. High-velocity layers represent Miocene basalts, whereas low-velocity layers represent sedimentary deposits between flows (Catchings and Mooney, 1988). This integrated structure reaches its maximum depth near the center of the Pasco basin (fig. 7). (2) A low-velocity layer beneath the Columbia River Basalt Group is interpreted by Catchings and Mooney (1988) as a pre-Miocene sedimentary basin. (3) A low-velocity layer (having a P-wave velocity of about $5.0 \mathrm{~km} / \mathrm{s}$ ) is contained within a graben structure that is evident in the mid and upper crust (fig. 7). The graben structure is about $70 \mathrm{~km}$ wide and has a vertical offset of about $4 \mathrm{~km}$ between the central axis and either side; the low-velocity sedimentary fill is thickest within the graben axis. (4) A lower crustal upwelling that has a seismic velocity of $7.5 \mathrm{~km} / \mathrm{s}$ occurs beneath the entire graben structure and reaches its highest crustal level of about $25 \mathrm{~km}$ below sea level directly beneath the center of the graben. Taken together, these four elements are typical of the structure of continental rifts (Catchings and Mooney, 1988).

The earthquake distribution (fig. 7) clearly shows a concentration of events within the Columbia River Basalt Group. Most of the shallow, crustal events within the Columbia River Basalt Group are near the Saddle Mountains, which occur over the northeastern edge of the 


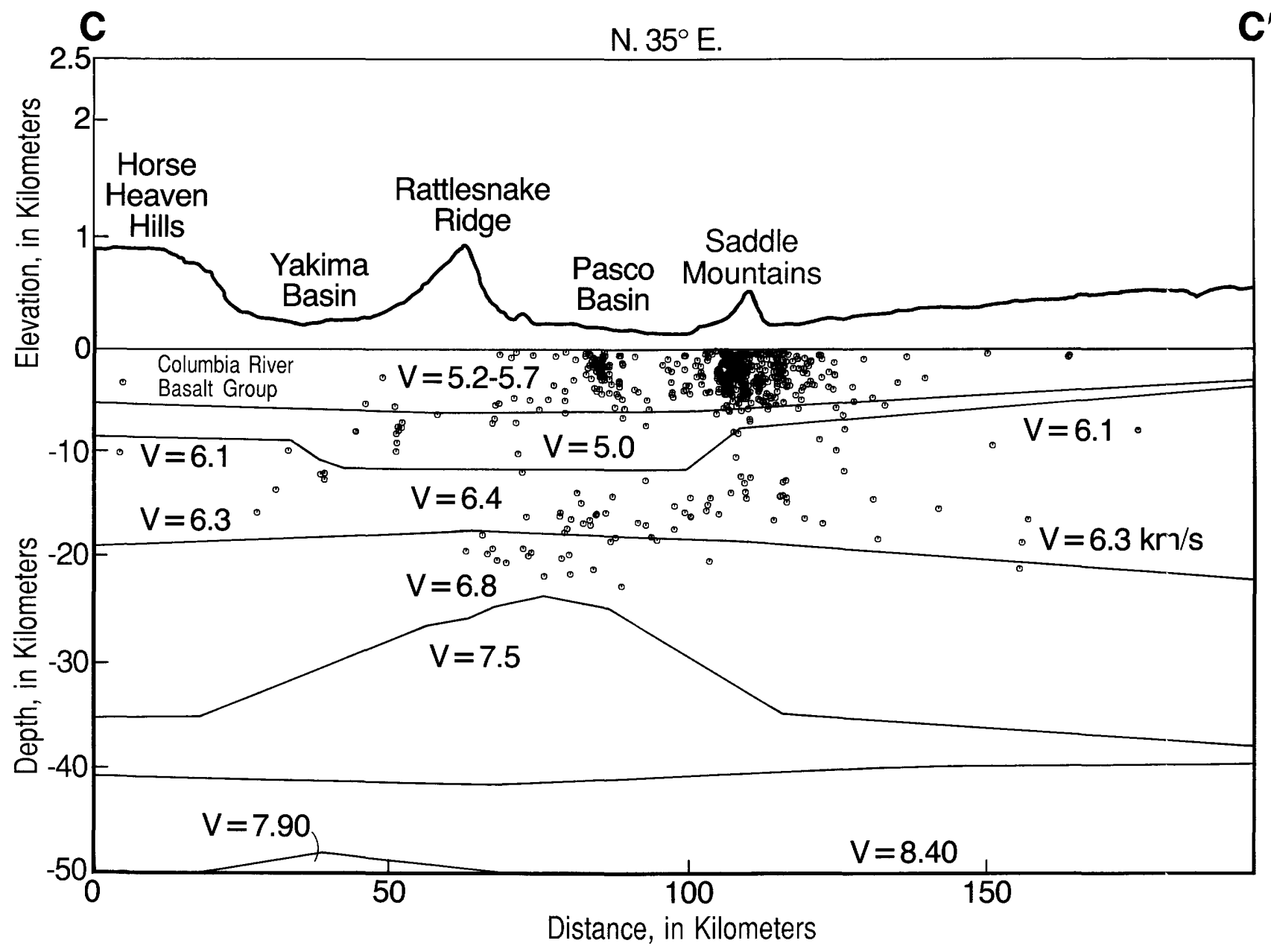

Figure 7. Crustal cross section $\left(C-C^{\prime}\right)$ in eastern Washington. Location of line of section shown on figure 6 . Vertical exaggeration of topography is 10:1; vertical exaggeration of subsurface is 1.8:1. CRBG, Columbia River Basalt Group; V, P-wave velocity of layer in kilometers per second. Earthquake hypocenters (since 1970), regardless of magnitude, shown by single symbol size. Earthquakes $50 \mathrm{~km}$ on either side of line C-C' (fig. 6) are projected onto a vertical plane striking N. $35^{\circ} \mathrm{E}$. From Ludwin and others (in press). Structural information from Catchings and Mooney (1988).

upper-crustal graben. The low-velocity sediments (having a P-wave velocity of about $5.0 \mathrm{~km} / \mathrm{s}$ ) are nearly devoid of earthquake hypocenters: the deeper crustal events are occurring in what is probably a granitic layer having a P-wave velocity of $6.1-6.4 \mathrm{~km} / \mathrm{s}$. The deepest crustal events (which are approximately $22 \mathrm{~km}$ deep) occur over the shallowest extent of the lower-crustal upwelling. Thus, the seismicity seems to be distributed unevenly about the upper-crustal graben: most events occur on the northeast side of the graben. The graben, though pre-dating the Columbia River Basalt Group and contemporary tectonics, apparently exerts some influence on the shallow crust and produces (or localizes) the Saddle Mountain system and contemporary seismicity. Although the processes responsible for localizing the shallow thrusts and earthquakes in the Pasco basin are unknown, there is a similar tendency for most of the earthquakes below the Columbia River Basalt Group to occur beneath the northeastern half of the graben (fig. 7).
Another example of the relation between crustal structure and earthquakes is the SHZ in southwestern Washington. Here, a combination of seismological, aeromagnetic, magnetotelluric, and volcanological studies have concluded that the SHZ represents a suture betw'een Tertiary marine volcanics to the west and a compressed marine forearc basin to the east (Stanley and others, 1990). The forearc basin is distinctive because it contains a huge conductivity anomaly (> 10,000 siemens $/ \mathrm{m}$ ); it is surrounded on three sides by a major, regional aeromagnetic low. Quaternary volcanism is voluminous on the edges of the basin but is extremely sparse within it; earthquake activity is concentrated predominantly along the boundaries of the basin. The SHZ occurs along the western boundary of the conductivity anomaly. The relation between the SHZ and other regional structures is an important component of a complete assessment of the hazards along the St. Helens zone; yet, no detailed seismic profiling of the crust has been done in this area. 
The earthquake hazards implications derived from the relation between crustal events and crustal structure have never been properly addressed in the Pacific Northwest. Results in the Pasco basin and along the SHZ show, however, the clear need for crustal structure studies to be integrated into the tectonic framework across the region.

\section{Intraplate Earthquakes}

Intraplate earthquakes (events within the subducting plate) are the most frequently observed of the large earthquakes in the historical record (magnitudes $\geq 6$ ). At least six large intraplate earthquakes are known to have occurred: in 1873, along the coast near the OregonCalifornia border, and in 1909, 1939, 1946, 1949, and 1965 , all within the Puget Sound basin (fig. 8). The source characteristics of intraplate earthquakes in the Pacific Northwest are fairly well known, but the spatial distribution of these events is uncertain. Intraplate events are generally believed to be caused by gravitational forces within subducting plates. Thus, the source region reflects the subducting plate depth and geometry. The depths of the largemagnitude intraplate earthquakes, based on the historical record, are estimated to be between 45 and $60 \mathrm{~km}$ (fig. 4).

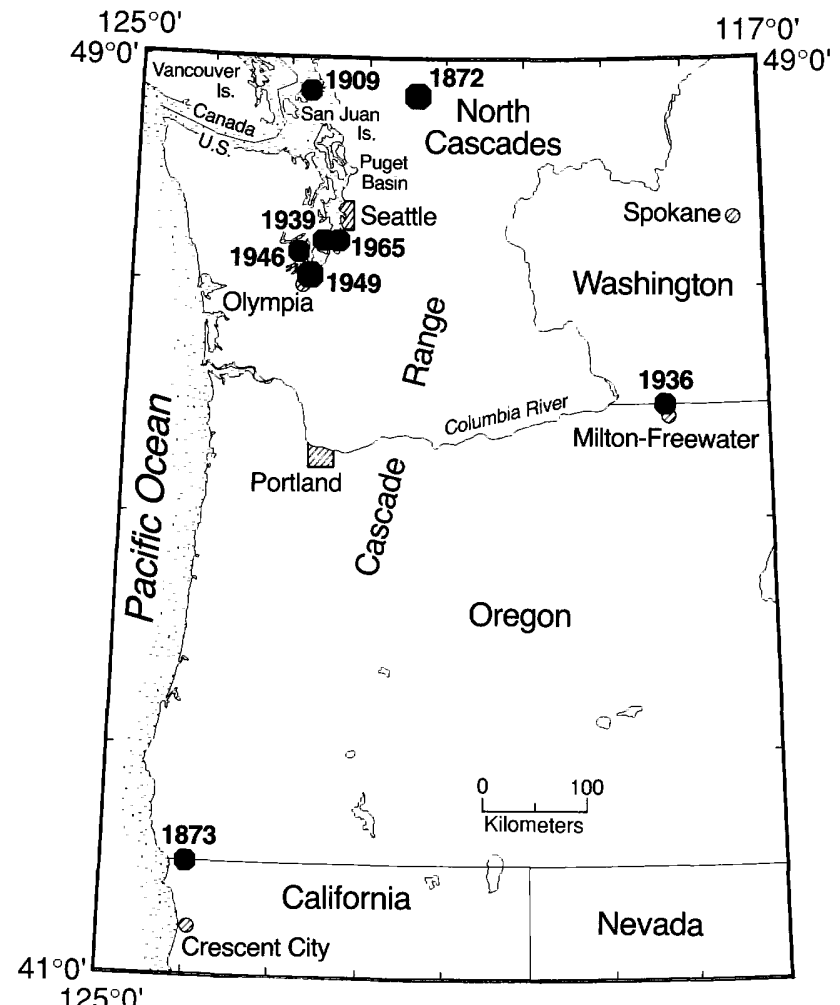

Figure 8. Map showing major damaging earthquakes in Oregon and Washington and year of occurrence. Small octagons are events having magnitudes estimated from felt areas to be between 6.0 and 6.9; large octagons are events with magnitudes estimated to be greater than 7 . From Ludwin and others (in press).
The distribution of intraplate earthquake hy oocenters indicates that the subducting Juan de Fuca plate arches upward beneath southern and central Puget Sound. Beneath southwestern Washington, the plate dips to the eastsoutheast, changing to a northeast-dipping plate beneath northwestern Washington (Weaver and Baker, 1988). Most of the large intraplate earthquakes (magnitude $\geq 6$ ) have been located in the southern Puget Sound basin; this leads to hypotheses that these events may not occur e'sewhere. However, because the plate is thought to be continuous everywhere between the trench and volcanic arc, intraplate events could occur anywhere that intraplate stresses reach some critical level. The major unresolved issue for intraplate earthquakes is whether they can occur be eeath the southern and central Oregon Coast Range, beneath northernmost California, and beneath central Vancouver Island. The plate geometry beneath most of Oregon is either poorly resolved or unknown because of low rates of seismicity and the sparse distribution of seismic network stations.

\section{Interplate earthquakes}

Some investigators (e.g., Heaton and Hartzell, 1986) have suggested that an earthquake as large as magnitude 9 (similar to the 1960 Chilean or 1964 Alaskan events) could occur along the coasts of northern California, Oregon, Washington, and southern British Columbia (fig. 9). In contrast to the crustal and intraplate earthquakes that have been instrumentally or historically recorded, the o:currence of interplate events must be inferred from the geologic record because no recorded earthquakes have occurred along the interface between the plates. Ongoing work in intertidal marshes along the Oregon, Washington, and northern California coasts has shown that the marsh stratigraphy includes alternating layers of buried peat and intertidal mud (Atwater, 1987). The sharp contacts between peat and overlying intertidal muds have been inte-preted as evidence for rapid coseismic subsidence of the tidal marshes in response to a large subduction earthquake. This evidence supports the concept that the Cascadia subduction zone has a number of similarities with other subduction zones around the world that have experienced frequent thrust-zone activity. In addition, the marsh studies may supply evidence of a locally generated tsunami coincident with a large earthquake.

The paradox in Oregon and Washington is that, despite the existence of a subduction zone, there are no contemporary thrust earthquakes on the shallow-dipping interface. The Cascadia subduction zone differs from nearly all convergent margins throughout the world because there is no great earthquake (magnitude $\geq 8$ ) in the historical record. However, studies of subduction-zone characteristics (Heaton and Kanamori, 1984; Heaton and Hartzell, 1986), strain accumulation in the region (Savage and others, 1981), and marsh stratigraphy along the Washington and Oregon 


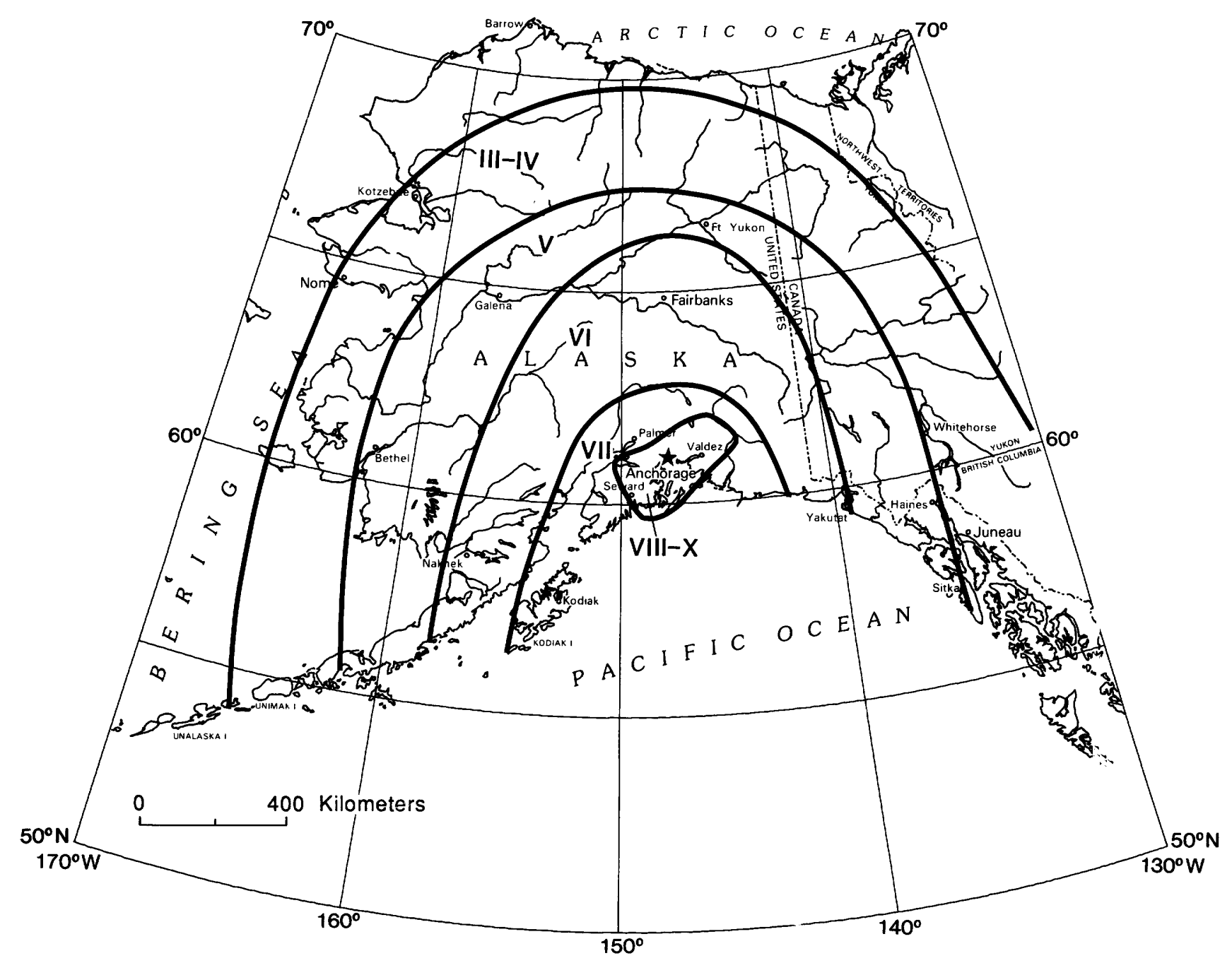

Figure 9. Map showing distribution of Modified Mercalli Intensities (MMI) for the 1964 Prince William So'..nd, Alaska, earthquake. $\mathrm{MMI}=\mathrm{VII}$ indicates the beginning of structural damage: cracked masonry; chimneys broken at the roofline; plaster, tile, and loose bricks fall; irrigation ditches damaged; etc. (The $\mathrm{MMI}=\mathrm{VII}$ contour encloses about $270,000 \mathrm{~km}^{2}$.) $\mathrm{MMI}^{2} \mathrm{X}$ represents an intensity sufficient to destroy most masonry and frame structures as well as bridges. $\mathrm{MMI}=\mathrm{XI}$ indicates destruction severe enough that lifelines and transportation systems are completely out of service. Modified from Espinosa and cthers (1986).

coasts (Atwater, 1987; Grant and others, 1989) provide evidence that the entire Cascadia subduction zone should be regarded as capable of generating large, interplate earthquakes. These observations spark debate about whether the thrust interface can be absolutely quiet at some point in the subduction cycle: Heaton and Kanamori (1984) compared the seismic quiesence along the Cascadia subduction zone with that on the northern section of the San Andreas fault that broke in 1906.

\section{Structure of the crust and lithosphere}

The composition of the crust of the Pacific Northwest has been investigated using geologic and geophysical methods, but there are few reversed, high-resolution refraction or wide-angle reflection profiles in the region. Mooney and Weaver (1989) summarized existing studies with a contour map of estimated crustal thickness beneath Washington, Oregon, and northern California (fig. 10). The sparse number of seismic lines emphasizes the need for deep seismic control in many areas.

There are two noteworthy features of $f$ oure 10 that relate to a working hypothesis for the configuration of the Moho. The first feature is the pronounced eastr'ard increase in crustal thickness from $16 \mathrm{~km}$ at the continental margin to about $40 \mathrm{~km}$ beneath the western flank of the Cascade Range. Gravity modeling along two profiles ir Oregon and preliminary interpretations of electrical and magnetic data collected by the EMSLAB experiment (EMSLAB Group, 1988) along a profile perpendicular to the northern Oregon coast are consistent with crustal thickening. The contours shown on figure 10 beneath the Klamath Mountains in 


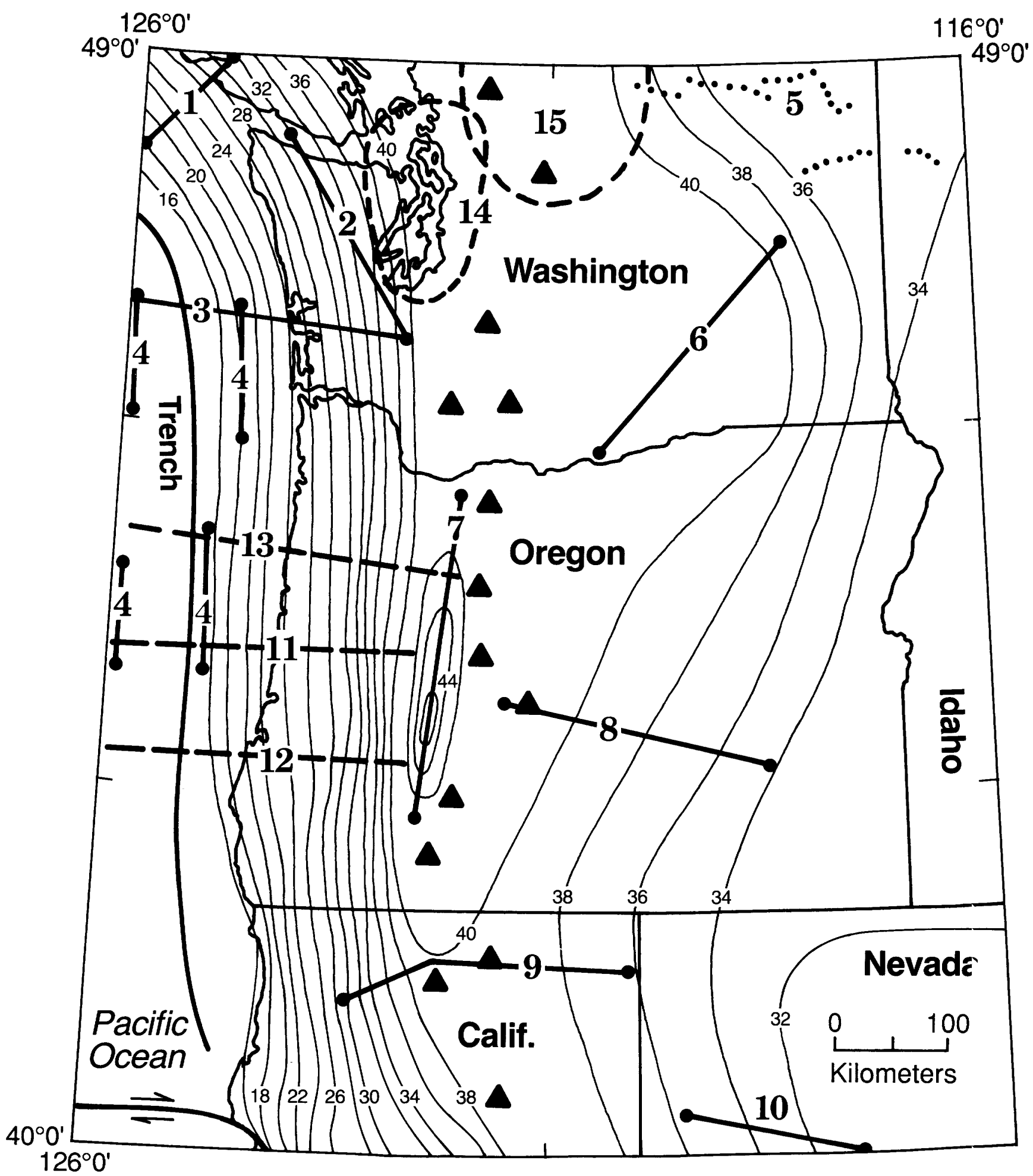

Figure 10. Contour map of crustal thickness (in kilometers) in the Pacific Northwest. Solid lines show locations of reversed refraction profiles (sometimes with other supporting geophysical data); dashed lines show locations of gravity or electromagnetic profiles; dotted lines show location of crustal reflection profiles; solid triangles, Quaternary stratovolcanoes. Areas enc'osed by dashed lines have had estimates of crustal thickness made from seismic array studies. From Mooney and Weaver (1989). 
southwestern Oregon and northwestern California lack seismic control. Nevertheless, the known, thin oceanic crust and thick Cascade Range crust support the general trends represented by the contours. The second major feature of the crustal thickness map is the presence of thick crust beneath the Cascade Range, the Puget Sound basin, and the Columbia Plateau (fig. 10). Crustal thickness is estimated to be at least $38 \mathrm{~km}$ over this entire region and locally reaches $46 \mathrm{~km}$ in the Cascade Range of southern Oregon. A gradual eastward thinning of the crust occurs beneath the Basin and Range of southeastern Oregon and northeastern California (fig. 10). The Moho shallows beneath the Okanogan Highlands in northeastern Washington, where a reflection profile (line 5 , fig. 10 ) has been interpreted as indicating a flat Moho at a depth of about $36 \mathrm{~km}$ beneath most of this province (Potter and others, 1986).

There are several unresolved scientific issues with respect to crustal structure. The first has to do with crustal earthquakes. In Washington, the deepest crustal events (approximately $30 \mathrm{~km}$ deep) are found near the point where the dip of the Juan de Fuca plate begins to steepen-generally, this is the area where plate depth is between 40 and $60 \mathrm{~km}$. The magnitude 7 and larger events on central Vancouver Island have source depths estimated to be in the mid to lower crust (Rogers and Hasegawa, 1978; Cassidy and others, 1988). These source depths have about the same relation to the subducting plate beneath Vancouver Island as that observed between the crustal activity in Puget Sound and the Juan de Fuca plate. Thus, better resolution of the deep crustal architecture is essential to determine if there are common features of the deep crust, presumably related to the subduction process, that are controlling the deep, seismogenic volume. Second, the SHZ is thought to represent the suture between Tertiary volcanic rocks to the west and a compressed marine forearc basin to the east; this boundary then acts to localize regional seismic slip along along its boundaries (Weaver and Malone, 1987). Crustal structure investigations along the $\mathrm{SHZ}$ would test this hypothesis and would allow insight into the distribution of earthquakes across much of southwestern Washington. Third, in the Puget Sound basin, crustal structure studies are needed to examine possible links between surface marine-terrace uplift, large Bouguer gravity anomolies in the central basin, and background seismicity at mid-crustal depths. Fourth, there is a need for a thorough examination of the geometry of the interface between the Juan de Fuca and North American plates. There are remaining questions concerning: (1) whether the interface is the actual slip surface for great megathrust events, (2) the landward extent of possible slip surfaces, and (3) whether major discontinuities might exist along the interface that could act as barriers to the generation of great earthquakes.

\section{Deformation Record}

Significant coseismic and permanent. vertical deformation often accompany the occurrence of great (magnitude $\geq 8$ ) subduction-zone thrust earthquakes. General characteristics of subduction-zone coseismic deformation may be summarized as follows (West, 1989, p. 36-37):

- Great earthquakes (magnitude $\geq 8$ ) generally affect more than $400 \mathrm{~km}$ of coastline (lirear distance); smaller magnitude earthquakes affect shorter lengths.

- Maximum uplift is between 2 and $6 \mathrm{~m}$ and occurs within $100-120 \mathrm{~km}$ of the trench; maximum subsidence is between 0.5 and $2.0 \mathrm{~m}$ and may occur as far as $275 \mathrm{~km}$ from the trench.

- "Multiple uplifted Holocene marine features (wavecut platforms, terraces, strandlines) are common to $30 \mathrm{~m}$ elevation in the zone of coseismic uplift and are evidence of past thrust events."

- Average rates of uplift vary between 0.2 and 4.0 $\mathrm{mm} / \mathrm{yr}$.

- "Geologically-derived recurrence intervals for great earthquakes indicate they have return periods of 300-2000 yr while historic records suggest the periods may be shorter (50-500 yr)."

West (1989) noted that the Pacific Northwest coastline includes five uplifted Pleistocene terraces but does not include uplifted Holocene features indicative of great subduction-zone earthquakes.

Several researchers (Atwater, 1987; Nelson, 1987; Peterson, 1989) have inferred periods of sutsidence based on episodes of marsh burial (fig. 11A). These authors infer that abrupt changes in microfossil assemblages, nonerosional upper contacts, and the thicknesses of overlying sand deposits favor tectonic subsidence and tsunamis as agents rather than storms or seiches. Evidence of episodes of subsidence that are likely coincident in time (and, hence, possibly coseismic with respect to a great subduction-zone earthquake) have been documented along the coast from southern Washington to northern California (fig. 11B). Localized subsidence and uplift have also beeา documented in the accretionary wedge of southern Oregon and northern California (Grant and others, 1989).

The lack of Holocene terrace uplift has been cited as evidence against repeated great subduction-zone earthquakes in the Pacific Northwest during the Holocene, while the areal extent and possible coincidence in time of rapid subsidence along the coasts of Washington and Oregon provide evidence for repeated earthquakes during Holocene time. This discrepancy may be explained by long recurrence intervals for great subduction-zone earthquakes (magnitude $\geq 8$ ) interspersed with smaller (magnitude $\cong 6-7$ ) thrust events-however, if this is the case, then the coast is in a unusually long period of seismic quiescence at the magnitude 6-7 level. A second possible explanation is that 


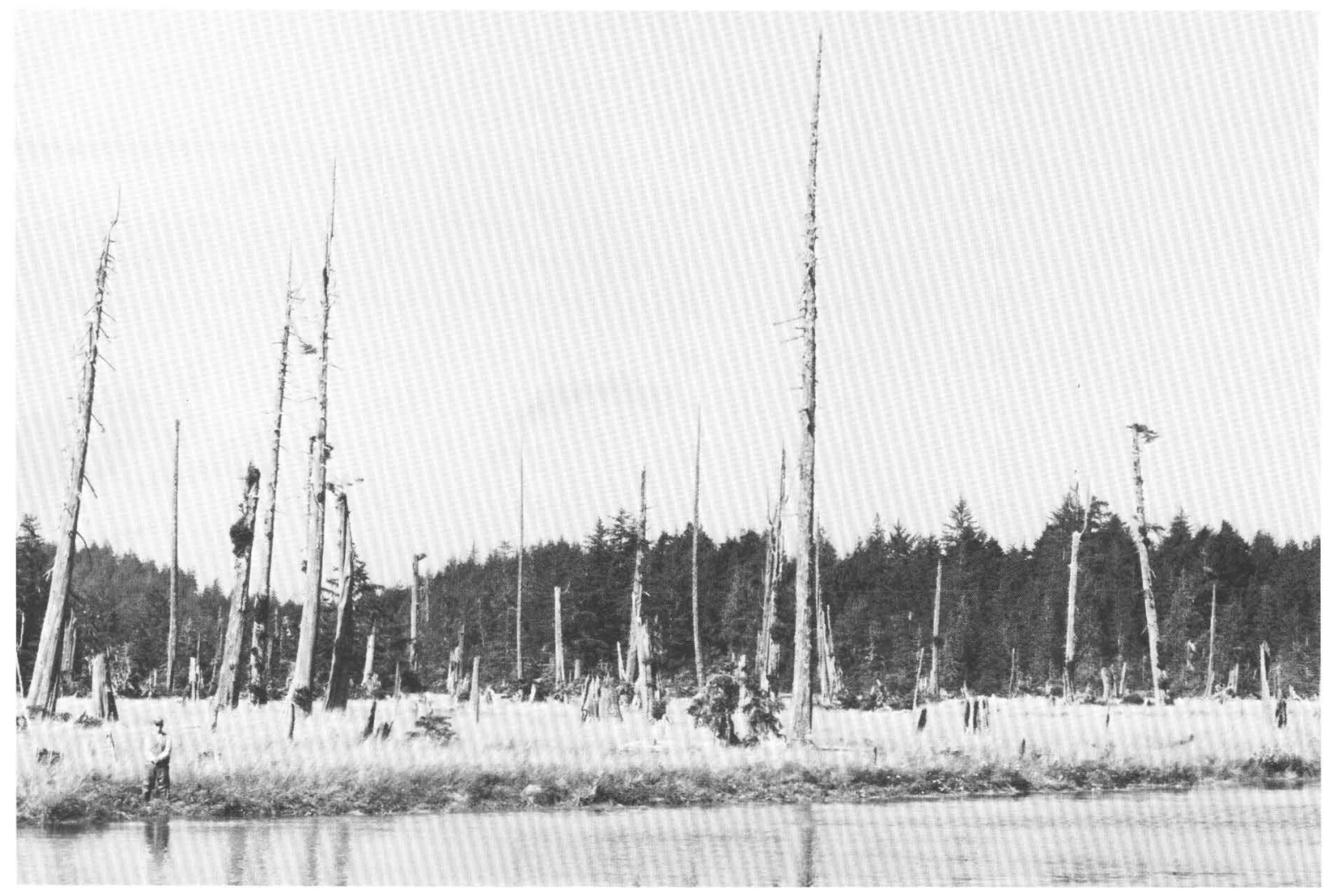

Figure 11. A, Photograph showing evidence for coastal subsidence, southwestern Washington. A ghost forest of cedar snags protrudes through an intertidal marsh along the Copalis River, Washington. The forest was probably killed after subsiding suddenly into the intertidal zone about 300 years ago. Man in lower left-hand corner of photograph is approximately $1.8 \mathrm{~m}$ tall. Photograph by B.F. Atwater; B, Location of sites (shown by solid circles) in Washington, Oregon, and northern California where coastal marsh stratigraphy studies are underway. Open triangles, Quaternary stratovolcanoes.

the behavior of coastal terraces is related to both the dip of the subducting plate and to details of the contact area between the two plates. It is clear that, although marsh stratigraphy may provide evidence of past, great thrust earthquakes, there is a pressing need to place coastal marsh sites into the proper regional geologic and tectonic framework.

\section{Geodetics}

Geodetic measurements indicate that crustal strain is accumulating in northwestern California, in the Puget Sound basin, and across the Strait of Georgia (fig. 12). The direction of principal contraction for each of the networks is generally close to the direction of relative plate convergence (N. $50^{\circ}$ E.) expected from the theoretical plate-motion

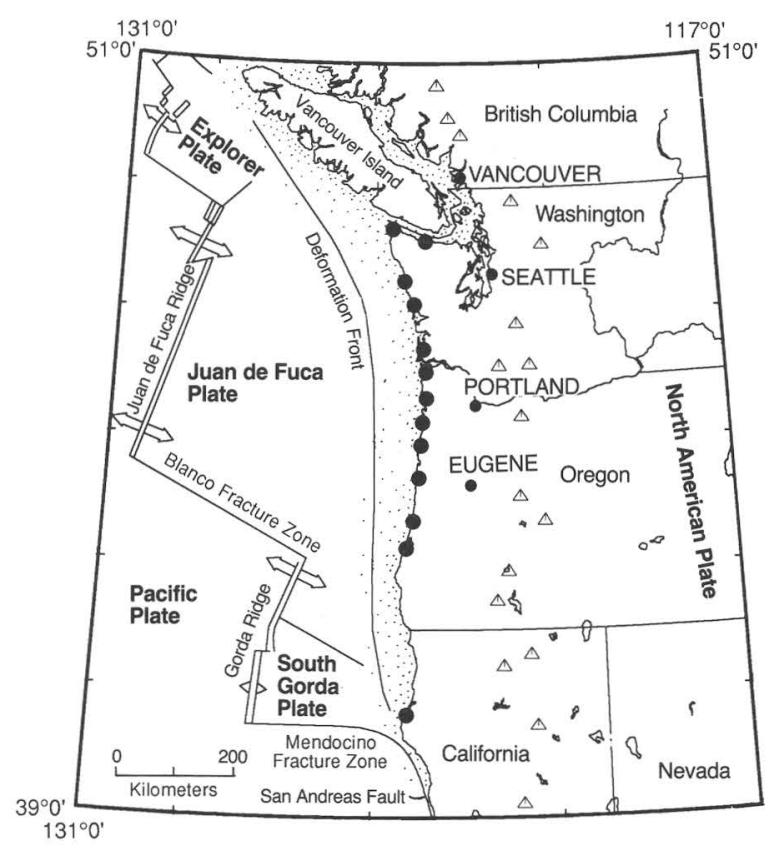

studies of Riddihough (1984). However, the rate of strain accumulation is slow, and, with the estimated uncertainty, the interpretation of contraction in the direction of relative convergence is not accepted unequivocally (Ando and Balazs, 1979; Sbar, 1983). Most modeling attempts (Savage 


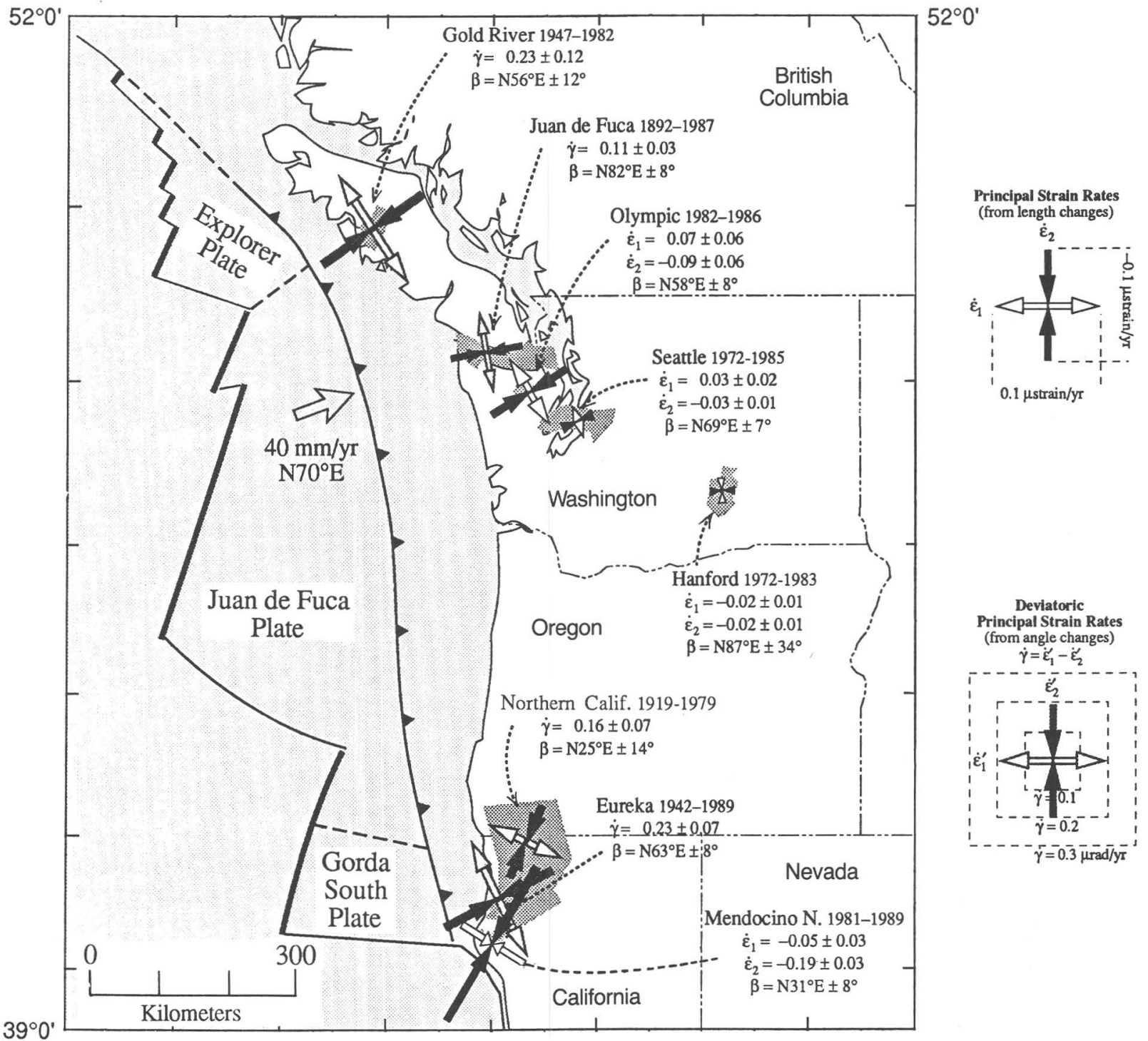

\section{$132^{\circ} 0^{\prime}$}

Figure 12. Map showing average strain accumulation rates (in parts per million per year) along the Cascadia subduction zone; calculated from repeated geodetic surveys. Areas covered by geodetic networks are shaded; average deviatoric or principal strain rates are shown with arrows. The network labels give the times of the initial and final surveys; the principal strain rates $\left(\varepsilon_{1}, \varepsilon_{2}\right.$, if distance changes are measured) or the total shear ( $\gamma$, if angle changes are measured); and the direction of maximum contraction (B). All results except those for northern California (Drew and Snay, 1989), Hanford (Prescott and Savage, 1984), and Gold River (Lisowski, 1985) are from unpublished USGS data. Rate and direction of convergence of the Juan de Fuca plate relative to the North American plate from DeMets and others (1987). Figure courtesy of M. Lisowski.

and others, 1981; Melosh, 1989) have been done for data collected over the arch in the Juan de Fuca plate; thus, it remains uncertain how appropriate the two-dimensional models are for a region of complicated three-dimensional structure. A particular problem is that, in the central Puget Sound basin, most earthquake focal mechanisms have P-axes striking nearly north-south, rather than N. $50^{\circ}$ E., and inversions for crustal stress directions show that the direction of maximum horizontal stress is north-south (Ma, 1988). Weaver and Smith (1983) suggested that there may be more than one crustal stress province in western Washington, perhaps because of major geological structures in the crust.

The uncertainty surrounding crustal strain in the Pacific Northwest may be resolved by improved network coverage and by the advent of the Global Position System 


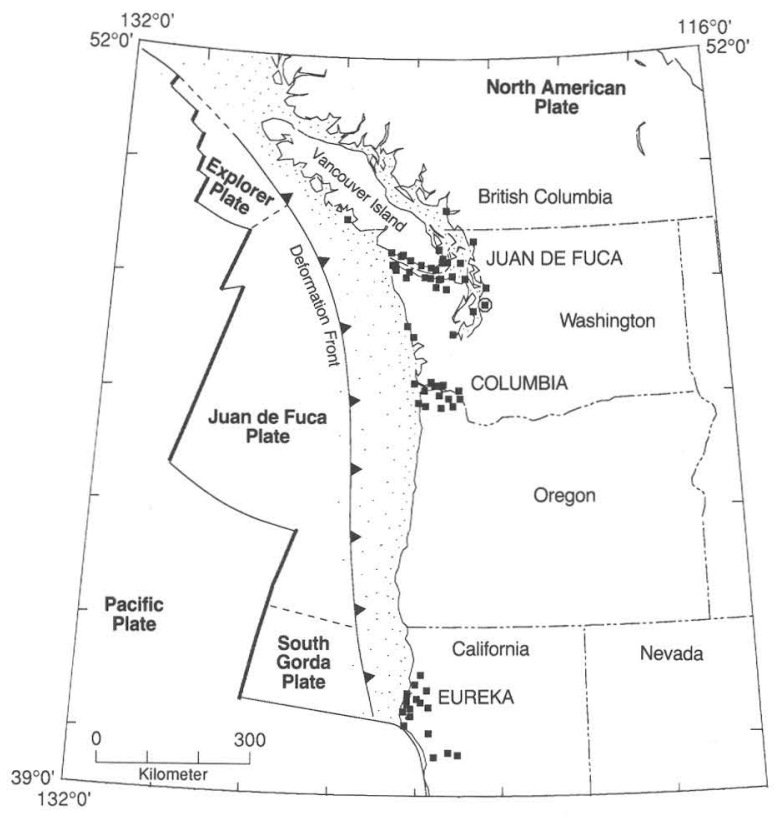

Figure 13. Map showing the locations of Global Positioning System (GPS) strain networks along the Cascadia subduction zone. Sites occupied with GPS receivers, solid squares. Surveys of the Juan de Fuca network were made in 1986, 1987, and 1989. Columbia and Eureka networks were surveyed in 1989. Many of these GPS measurements were made in order to recover the position of historical triangulation stations. Figure courtesy of M. Lisowski.

(GPS) for making very high resolution geodetic surveys. The current distribution of GPS stations is shown along the coast of the Pacific Northwest in figure 13; this network will have to be expanded both along the coast and inland to the volcanic arc. In fact, it is a desirable program goal to integrate a regional GPS network designed to examine plate-scale strain accumulation with additional dense networks of stations around selected volcanic areas (Mount Rainier, Mount St. Helens, Medicine Lake, Mount Shasta, Lassen Peak, and Mount Hood) and other active, tectonic structures.

\section{Ground Failure}

One of the most disastrous natural hazards scenarios that one might imagine in Washington involves the repeat of the Osceola debris flow of about 5,700 years ago (fig. 14). Originating high on the slopes of Mount Rainier, this debris flow covered approximately $70 \mathrm{~km}^{2}$ of the flood plain of the White River and nearly reached Puget Sound at Tacoma (Crandell, 1971). Despite the fact that the source zone was a volcano, it is possible that this debris flow may not have been of volcanic origin (R.L. Schuster, oral commun., 1989). The rockslide/debris avalanche (volume $\cong 2.8 \mathrm{~km}^{3}$ ) associated with the 1980 eruption of Mount St. Helens destroyed much of the public and private property along the sparsely populated North Fork of the Toutle River valley (Schuster, 1983). Earthquake-induced ground failures (primarily landslides and liquefaction events) occurred throughout an area of about $30,000 \mathrm{~km}^{2}$ as a result of the 1949 earthquake; the 1965 earthquake caused ground failures throughout an area of about $20,000 \mathrm{~km}^{2}$ (Keefer, 1983).

Earthquake-induced landslides in Washington State have been documented for 14 earthquakes between 1872 and 1980 (Noson and others, 1988). There is an ongoing controversy concerning the extent of landslides associated with the 1872 earthquake (the largest known earthquake in Oregon or Washington). One group of researchers has suggested that the Ribbon Cliffs rockslide, a prominent feature along the Columbia River north of Wenatchee, was triggered by the 1872 earthquake and temporarily dammed the Columbia River in north-central Washington (Weston Geophysical Research, Inc., 1976). A study by Kienle and others (1978) suggested that the Ribbon Cliffs rockslide may not have been activated by the 1872 earthquake: it may, instead, have had a longer history of activity. Given the nature of the morphology and the materials involved, the slide is most likely earthquake induced (R.L. Schuster, oral commun., 1989). Landslides triggered by the 1949 and 1965 earthquakes significantly damaged lifelines and property in the Puget Sound basin (Chleborad and Schuster, 1989). Given the similarities in the climate, geology, and physiography of Washington and Oregon, the lower level of seismicity in Oregon is primarily responsible for the lower level of losses due to earthquake-induced landslides. An increase in seismicity would be accompanied by increased landslide activity. Though the losses associated with historical earthquake-induced landslides in the Pacific Northwest have not been catastrophic, the risk to lifelines and rescue efforts cannot be underestimated.

Liquefaction (the loss of internal coherency in shallow layers of sand buried beneath the water table) is another type of ground failure induced by earthquakes (fig. 15). Most commonly, liquefaction causes loss of bearing capacity and results in differential settlement, buoyancy, or lateral displacement of engineered structures such as buildings, bridges, towers, storage tanks, and roadways. Much of the loss during the 1964 Alaska and 1989 Loma Prieta earthquakes was attributed to liquefaction. Liquefaction susceptibility is highest in young, alluvial deposits or in artificial fills in areas with high ground-water levels (i.e., adjacent to waterways). Thus, most of the major urban areas in the Pacific Northwest have areas of high liquefaction susceptibility. Soil liquefaction as far as 120 $\mathrm{km}$ from the epicenter has been documented for the 1949 Puget Sound basin earthquake and as far as $36 \mathrm{~km}$ from the 1965 earthquake epicenter (Keefer, 1983). Liquefaction effects have occurred in areas experiencing Modified Mercalli Intensities (MMI) as low as VII (Keefer, 1983). 


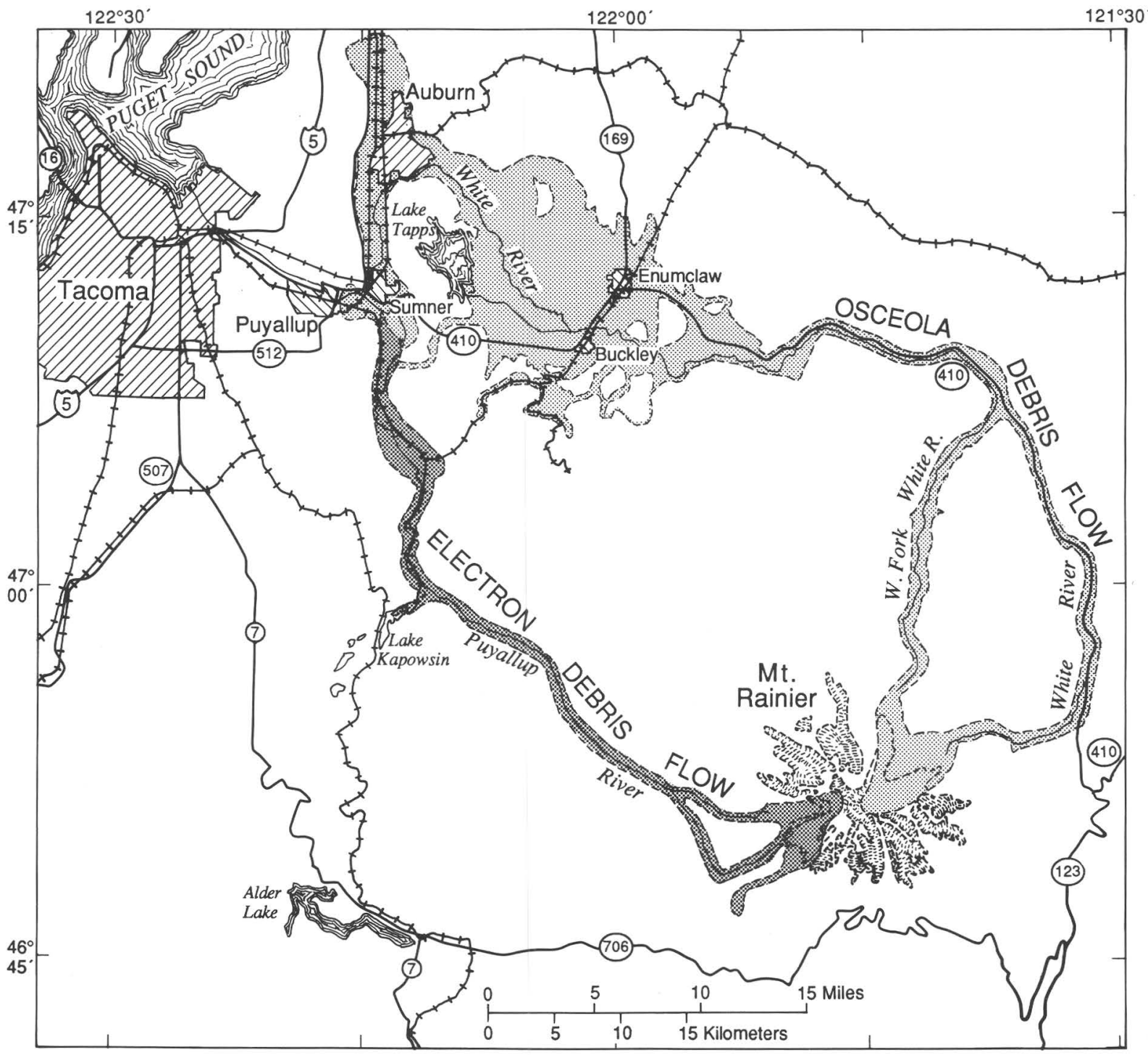

Figure 14. Map showing the Osceola debris flow, which originated high on the slopes of Mount Rainier about 5,700 years ago and flowed down both branches of the White River. A repeat of this debris flow would essentially bury the cities of Puyallup, Sumner, Buckley, Enumclaw, and Auburn, along with several highways and railroad tracks; this would seriously hamper any response efforts.

The occurrence of a great subduction-zone earthquake, or even crustal earthquakes with magnitudes of about 6-7 near urban areas in the Pacific Northwest, could result in high liquefaction losses.

\section{Strong Ground-Motion and Structural Response}

Quantitative estimates of the characteristics of strong motion and structural response are essential structural engineering components of regional seismic hazard and risk assessments. Estimates of ground motion are made for a variety of applications: earthquake-resistant design provisions for building codes, disaster mitigation, land-use planning, as input to the assessment of earthquake-related ground-failure hazards, and as input to evaluations of earthquake risk.

Source depths are the largest factors controlling quantitative strong ground-motion in the Pacific Northwest. Strong ground-motion records exist from the 1949 and 1965 Puget Sound basin earthquakes, which had source depths of 54 and $60 \mathrm{~km}$, respectively (i.e., these were intraplate earthquakes). Langston (1981) attempted to model observed 


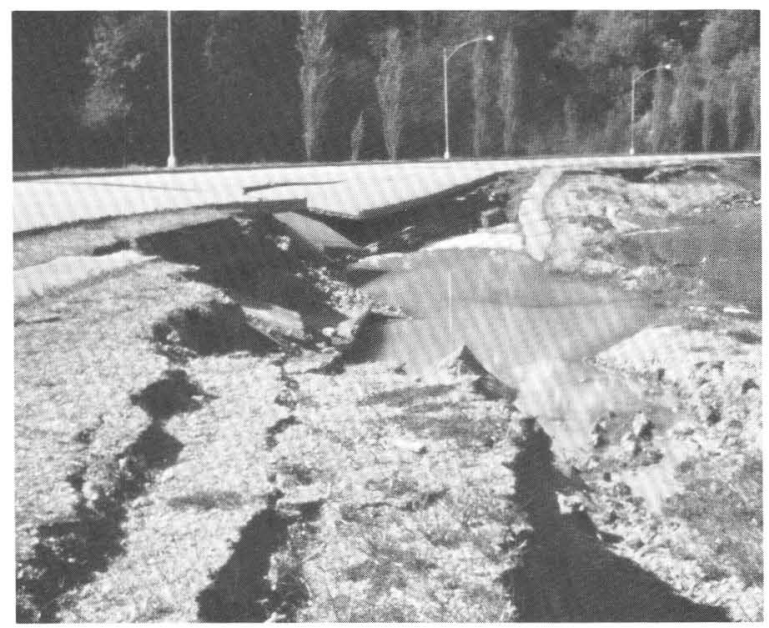

Figure 15. Photograph showing damage to Deschutes Parkway, Olympia, Washington, resulting from ground failure induced by the 1965 earthquake. The Parkway was constructed on granular fill placed on tidal-flat muds; failure was probably due to liquefaction. Streetlights in photograph are approximately $8 \mathrm{~m}$ high. Photograph by G.W. Thorsen, Division of Geology, Washington Department of Natural Resources.

strong motion velocities and displacements recorded at three locations within the Puget Sound basin for the 1965 earthquake. He illustrated that strong motion in the basin generally exhibited the characteristics of near-vertical wave propagation in layered structures but also exhibited complex site amplitude behaviors. Higher attenuation beneath Seattle and Tacoma relative to Olympia, though not strictly required, explains this complexity. Using teleseismic data to help constrain the velocity structure, Langston (1981) found evidence of dipping, large velocity-contrast interfaces and other heterogeneity beneath Olympia. The maximum acceleration observed anywhere in the basin was about 0.2 $g$ (this is relatively low for a magnitude 6.5 earthquake when compared to accelerations $>1.0 \mathrm{~g}$ observed for the 1971 San Fernando and 1979 Imperial Valley earthquakes). Langston (1981, p. 901) attributes this to depth, noting that, If it is reasonably assumed that the 1965 accelerations are dominated by body waves, then they may be approximately corrected back to a point near the source using geometrical spreading. If the source was $10 \mathrm{~km}$ from Olympia rather than about $100 \mathrm{~km}$, accelerations could have been as high as $2 \mathrm{~g}$ using this simple technique. Accelerations for the 1949 event show values slightly larger than those observed for the 1965 event. If the source was shallower at $10 \mathrm{~km}$ rather than 70 (Nuttli, 1952), the geometric spreading correction again gives values greater than $2 \mathrm{~g}$.

Based on these analyses, Langston (1981) summarized that attenuation and lateral heterogeneity are second-order wave-propagation considerations compared to source depth; this biases strong ground-motion estimation for the Pacific Northwest.

In the first of a sequence of papers leading to estimates of ground motions from plausible Cascadia subduction-zone earthquakes (i.e., interplate earthquakes), Heaton and Kanamori (1984) illustrated that the Cascadia subduction zone shares many tectonic characteristics with other strongly coupled subduction zones worldwide. Thus, Heaton and Kanamori (1984) concluded that the Cascadia subduction zone may be capable of producing great (magnitude $\geq 8$ ) shallow earthquakes.

Noting that few strong ground-motion records exist for great subduction-zone earthquakes, Hartzell and Heaton (1985) examined teleseismic source time functions for earthquakes in subduction zones worldwide. They illustrated that these functions may be used to constrain earthquake source parameters in similar subduction zones for which little or no strong ground-motion has been recorded. These source descriptions may then be used to synthesize near-source strong-motion records-estimates of frequency content and seismic radiation necessary for seismic-design purposes may then be made.

Heaton and Hartzell (1986) analyzed trench bathymetry, free-air gravity profiles, seismicity, subductionzone length, width of continental margin, heat flow, Quaternary volcanism, and other characteristics of subduction zones and determined that the Cascadia subduction zone is most similar to the subduction zones of southern Chile, southwestern Japan, and Colombia. Unlike the Cascadia subduction zone, however, the historical seismicity record of each of these three similar subduction zones contains at least one great (magnitude $\geq 8$ ) shallow subduction-zone earthquake. Heaton and Hartzell (1986) then proposed several hypothetical earthquake sequences for the Cascadia subduction zone.

Heaton and Hartzell (1989) used the empirical Green's function technique to synthesize strong groundmotions that could result from the occurrence of these hypothetical earthquakes on the Cascadia subduction zone. They illustrated that relatively strong shaking occurs as far as several hundred $\mathrm{km}$ from magnitude 8 earthquakes. The great subduction-zone earthquake synthetic responsespectra produced for the coast ranges are, at all frequencies, comparable to or smaller than the response spectrum from the 1971 San Fernando earthquake, which is among the largest motions recorded for any earthquake. Thus, Heaton and Hartzell (1989) have inferred that a great subductionzone earthquake in the Pacific Northwest will produce strong shaking over a large region.

Cohee and others (1991) extended the above methodology to simulate more regionally specific ground motions from a great subduction-zone earthquake at an array of stations covering coastal Washington and Oregon. 
Their approach allowed estimation of the variability of ground motion due to differences in the location of the hypocenter and rupture surface. They assumed a velocity structure for Cascadia adapted from a geophysical transect across the Cascadia margin; fault geometries were adapted from several researchers. They simulated strong groundmotions at both rock (i.e., Coast Range) and soil (i.e., Seattle) sites in this regionally specific crust/lithosphere structure. They illustrated that stations close to the subduction zone will experience large ground motions for a relatively brief time and more distant stations will experience moderate ground motion for longer intervals (about 1 minute). Somerville and others (1989) further refined the method and concluded that, (1) the response spectral velocities in the Seattle-Portland region would be about twice those recorded during the 1949 and 1965 earthquakes, (2) the duration of strong motion would be longer ( $60 \mathrm{~s}$ instead of 10-20 s), and, (3) ground motions at periods longer than $1 \mathrm{~s}$ would be substantially larger. Thus, structures with long natural periods (i.e., multistory buildings) or structures harmonically responsive to long durations (i.e., bridges, storage tank farms, etc.) would be severely damaged, if not completely destroyed, by the occurrence of a great subduction-zone earthquake.

Site effects (subsurface geologic conditions, in particular) play a complicated role in ground shaking and building damage in the Pacific Northwest (Yount, 1983). Ground-motion amplification is common at sites underlain by unconsolidated deposits over bedrock (Idriss and Seed, 1968). Yount (1983) examined the subsurface geology of the Seattle area and the ground shaking effects reported for the 1965 earthquake. He reported that areas underlain by alluvium, fill, and water-saturated sand (low-impedance units) showed strong shaking effects where bedrock was near the unit but that shaking was attenuated where thick $(>100 \mathrm{~m})$ sequences of semiconsolidated Quaternary sediments separated bedrock and low-impedance units.

\section{FRAMEWORK FOR NEHRP STUDIES}

The characterization of geologic hazards in the Pacific Northwest faces a fundamental obstacle: here, more clearly than anywhere else in the conterminous 48 states, there is an overlap between hazards posed by volcanos, earthquakes, and landslides. Further, the fundamental tools to study the processes responsible for these hazards, such as seismic networks and Quaternary mapping, cut across existing program responsibilities. The overlap among geologic hazards occurs, in part, as a result of the multiple nature of an initial hazard (for example, an earthquake) that may subsequently trigger secondary hazards (typically ground failure, a tsunami, and, unique to the Pacific Northwest, perhaps a volcanic eruption) and, in part, because common sources may also trigger multiple hazards. Heavy precipitation may cause flooding and debris and (or) mud flows. Despite the multiple nature of both processes and hazards, geologic hazard studies and mitigation programs are commonly divided into studies of individual hazards.

The separation of hazard studies by program or discipline is particularly limiting in areas like the Pacific Northwest where, for example, earthquake hazards are poorly understood and a variety of scientific opinion exists surrounding individual aspects of the hazards problem. Nonetheless, the USGS must contribute to detailed studies of hazards and risk assessment in urban areas, to framework studies on regional and local scales, and to plate-scale studies of the subduction environment. There are four necessary components of the USGS/NEHRP program designed to address, in varying degrees, the spatial characteristics, expected magnitudes, recurrence intervals, ambient strain, source characteristics, site response, and attenuation associated with the three types of earthquakes known to occur in subduction zones like those in the Pacific Northwest. The immediate need for hazards and risk assessments in urban areas is obvious, and a variety of regional and local geologic and geophysical studies are therefore necessary. Furthermore, a comprehensive assessment of the capability of the subduction interface to produce earthquakes possibly as large as magnitude 9 makes platescale experiments mandatory for hazard determinations. In addition, the complementary study of the nature and evolution of magmatic arcs, central to the subduction regime of this region, allows development of comprehensive tectonic models that can anchor hazards assessments.

\section{Necessary Program Components}

\section{Monitoring seismicity and deformation in the Pacific Northwest}

- Upgrade, expand, and maintain the seismic network to monitor earthquakes in the Pacific Northwest.

- Deploy a network to monitor crustal deformation in the Pacific Northwest.

The coordinated operation and maintenance of expanded regional seismic networks, appropriate U.S. National Seismograph Network (USNSN) stations, and an array of strong-motion stations from Cape Mendocino to the Canadian border and from the coast inland across the Cascade Range are necessary. The Earthquake Program should fund an appropriate portion of the network, including the installation of enough new stations in southwestern Oregon to provide monitoring capability of the entire subduction zone (fig. 16). Appropriate USNSN stations should be installed, and the data from these stations should be made available to academic institutions in the Pacific Northwest. Regional monitoring of Cascade Range 


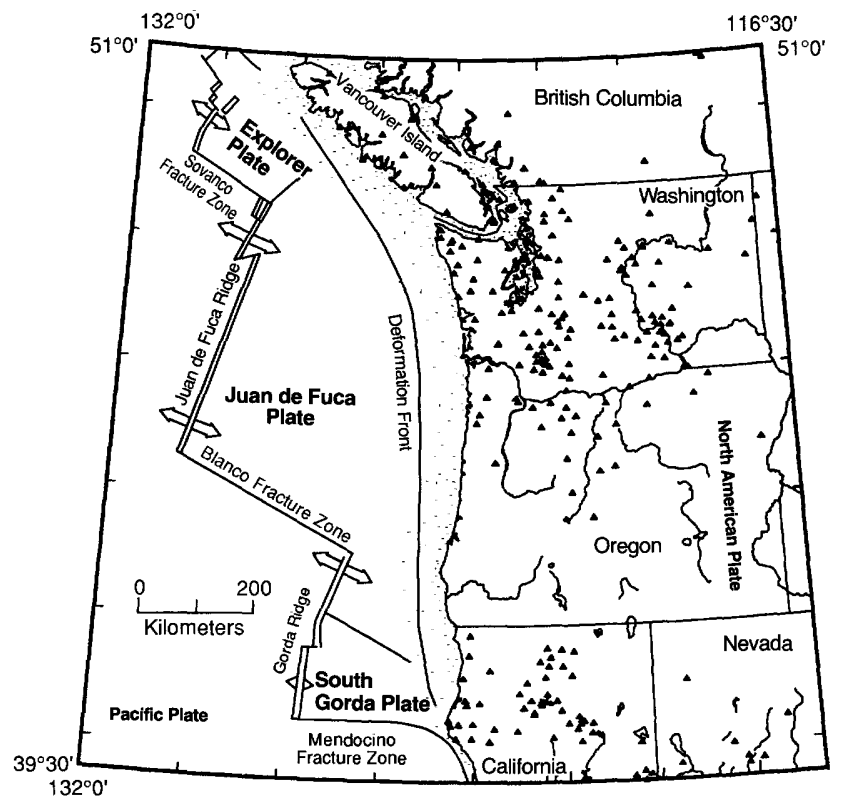

Figure 16. Map showing regional seismic network stations in the Pacific Northwest. Solid triangles represent stations operating on August 1, 1990. Most stations in British Columbia are operated by the Geological Survey of Canada in Sidney; stations in Washington and Oregon are operated by the University of Washington; stations in Nevada are part of the University of Nevada at Reno network; most stations in California are part of the U.S. Geological Survey "Calnet" operated in Menlo Park.

volcanoes, except Mount St. Helens, falls within this objective.

Free-field strong-motion instrumentation needs to be installed at new sites in Oregon, additional sites in Washington (particularly in the Pasco basin and along the SHZ), as well as in representative coastal areas of northern California (fig. 17). This objective includes expanding the existing short-period network (operated by the University of Washington) in Oregon and Washington and linking it with the northern California portion of the USGS network operated in Menlo Park. Data from these short-period networks, as well as the network operated by the Geological Survey of Canada, should utilize the real-time, digital telemetry and storage systems being designed for the USNSN. A regionally based research center that would maintain the seismic and strong-motion networks, archive the data collected, perform routine processing, and provide basic data to all researchers should be formally established. The University of Washington performs most of these functions currently-thus, expansion of their program with resources to provide better linkage to State surveys and interested regional universities and the formal designation of the University of Washington as a regional earthquake study center should be considered.

The purpose of this monitoring is to obtain a much better description of potential earthquake sources in the

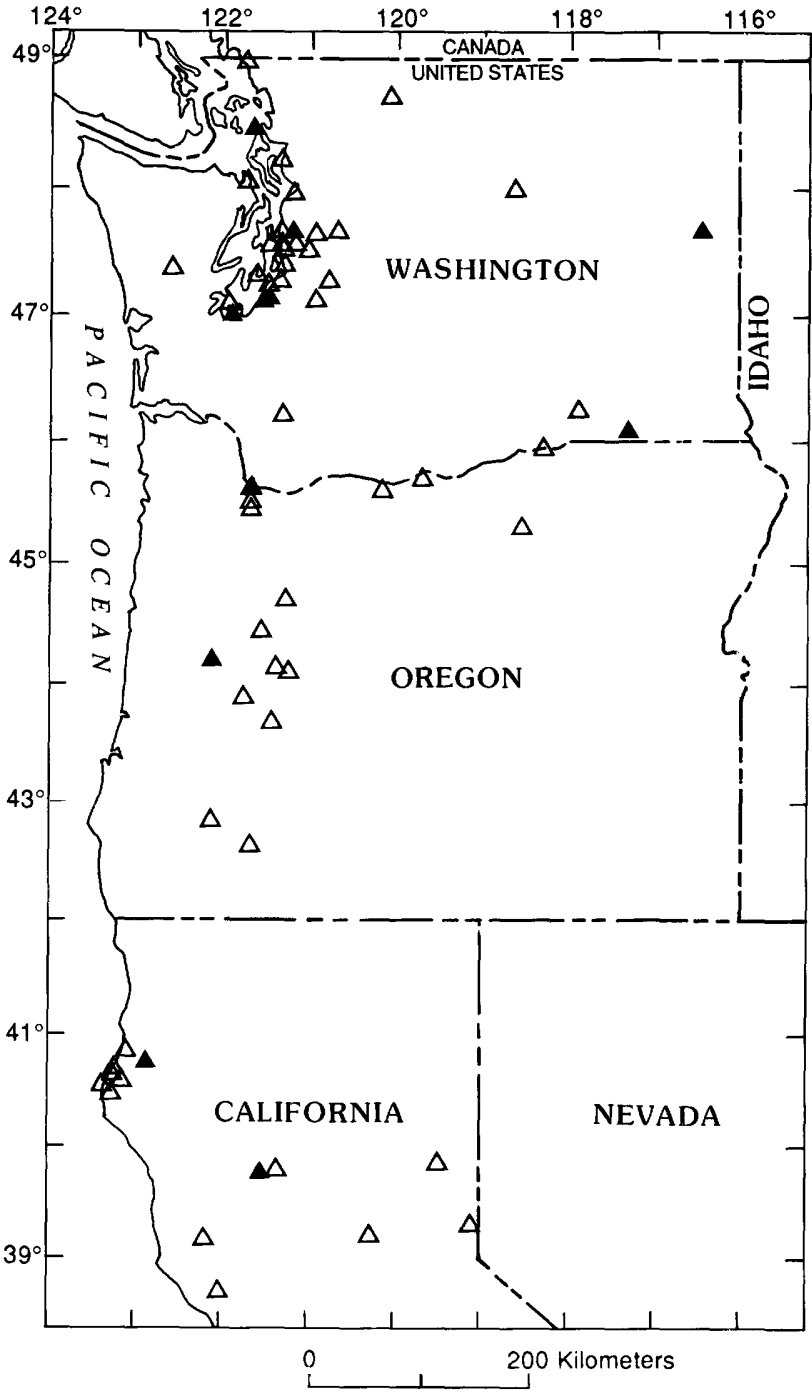

Figure 17. Map showing strong-motion accelerometer stations operating in the Pacific Northwest. Open triangles mark locations of stations installed either within or on engineered structures; solid triangles are free-field or ground sites. Accelerometers are generally set to trigger when ground acceleration exceeds $0.01 \mathrm{~g}$; this corresponds to a local earthquake of approximate magnitude 4.5 or larger. Strongmotion stations do not record initial P-wave motions; instead, they record subsequent motions of the building or ground.

Pacific Northwest. This description by necessity will recognize the three different source zones. Expanded seismic monitoring will determine if the Juan de Fuca plate teneath central and southern Oregon is truly aseismic.

The development of a crustal deformation netivork to identify and (or) quantify accumulated strain should be encouraged. Initial deployment probably should be undertaken along the strike of the subduction zore. The development of Global Positioning System (GPS) technology makes this a realistic goal, and such an effort is required by the large source region of potential subductionzone earthquakes. The present GPS network (fig. 17) does 
not unequivocally provide the data necessary to distinguish between the possibility of a great subduction zone on the interface (involving source dimensions of hundreds of kilometers) and more local events (perhaps in the magnitude 7 and above range). This objective includes the need for detailed monitoring of deformation at selected Cascade Range volcanoes and other active tectonic structures as they are identified. Close coordination with and participation in experiments with the Geological Survey of Canada is necessary; the current experiment across the Strait of Georgia should be continued.

\section{Tectonic Framework Studies}

- Integrate geologic and geophysical studies to better understand the tectonic regime of the Pacific Northwest.

- Define the geometry of the subduction-zone interface.

- Determine the spatial, temporal, and source characteristics of damaging earthquakes in the Pacific Northwest.

The tectonics of the Pacific Northwest subduction zone must be well understood. Despite comparisons between the Cascadia subduction zone and other zones around the world and geological evidence of movement during Holocene time along the Washington and Oregon coasts, the lack of seismicity on the thrust interface between the Juan de Fuca and the North American plates makes analysis of the potential for great thrust earthquakes equivocal. The data recorded by the expanded network, combined with the additional broad-band data collected by the USNSN, will provide the data base necessary for sophisticated structural modeling of the Juan de Fuca-North American plate interaction. In the absence of earthquake activity on the thrust interface, other data that will allow the definition of active processes occurring in the subduction zone are needed for a complete assessment of the hazards facing this region. Processes such as tectonic underplating in the thrust interface zone, splay faulting in coastal margins, active magmatism of the andesitic arc, or the interaction of backarc extension in the Basin and Range with subduction tectonics of the forearc region need to be understood to allow earthquake hazards of the Cascadia subduction zone to be placed in the proper plate tectonic framework. Central to these data is an understanding of the long-term effects of convergent margin tectonics on the crust of North America and on the interface between the two plates. In particular, bedrock mapping of critical areas at a 1:250,000 scale (i.e., Bellingham and Vancouver, Washington) must be completed. Tectonic syntheses of seismic, geodetic, geologic, gravity, and other data must be undertaken; these studies should include Geographical Information Systems (GIS) approaches. A regional GIS data base must be established.
This component of the program includes Quaternary studies in the Puget Sound basin and Willamette Lowland. All of the ongoing studies of Quaternary geology (geologic mapping, stratigraphy, paleoseismicity) need to be continued and expanded appropriately to realistically constrain ground-motion studies and associated shaking hazards. This component also includes investigations of the nature of the late Quaternary record of deformation. This effort is currently underway along numerous portions of the Pacific coast and is largely responsible for the rapidly growing acceptance of the possibility of great thrust earthquakes in the Pacific Northwest. The observations and interpretations of coastal marsh-zone stratigraphy need to be rigorously tested and debated. This component has recently been expanded into the Puget Sound basin and includes field studies of evidence of deformation, the modeling of such evidence, and the incorporation of these observations and models into the larger plate tectonic and structural setting.

The Earthquake Program must suppct a comprehensive series of seismic, magnetotelluric, and geologic studies aimed at understanding the crustal architecture. The new Deep Continental Studies (DCS) Pacific Northwest study provides a vehicle for Earthquake Program funding to help define the issues of interest to the DCS program and to considerably broaden the scope of DCS invest gations in the region. Earthquake Program funding should be targeted to investigate the nature of the thrust interface ty means of a series of north-south profiles in Washington and northern Oregon (fig. 17); these profiles would serve as strike-lines for an east-west transect from the Grays Harbor, Washington, area eastward across the Columbia Plateau and could possibly be conducted in conjunction with offshore experiments under the EDGE program of the National Science Foundation. The Earthquake Program should take advantage of the unique prospect of seismic and magnetotelluric profiling in northern California across the landward extension of the fold and thrust belt that forms the offshore deformation front. Finally, crustal-structure investigations are needed of local features such as the central Puget Sound basin, where recent evidence of late Holocene uplift of marine terraces may indicate large, crustal earthquake activity in heavily populated urban areas.

\section{Improve Seismic Hazard and Risk Assessments}

- Delineate zones corresponding to each cf the three types of seismic sources.

- Identify areas expected to experience strong ground shaking and (or) amplification from each of the different types seismic sources.

- Identify areas subject to ground failure, including liquefaction.

- Encourage loss-estimation studies, including inventories and responses of man-made structures. 


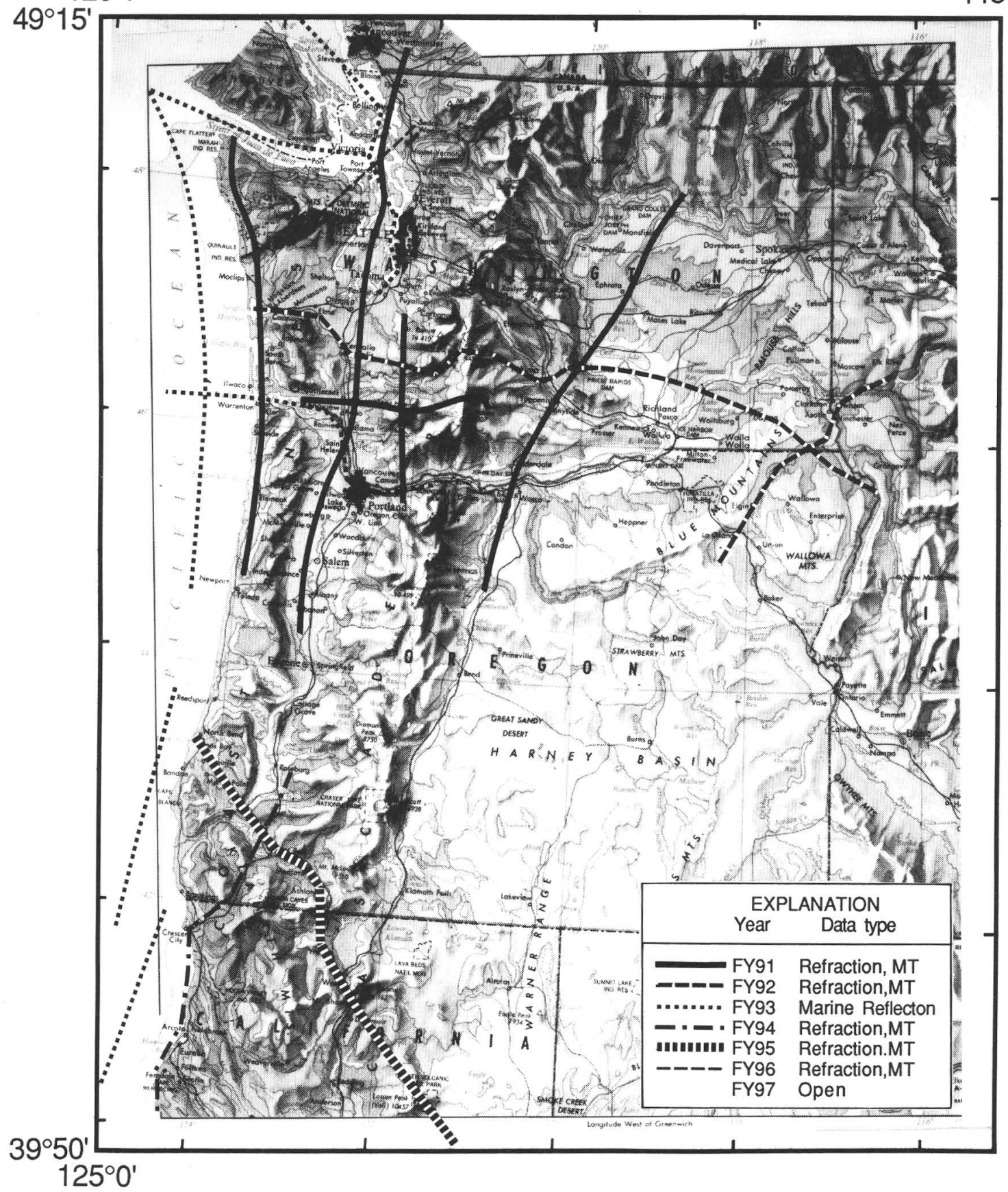

Figure 18. Map showing proposed locations of crustal structure profiles to be funded either completely or in part by the Earthquake Program. These profiles will be planned in conjunction with the USCS Deep Continental Studies Program, Pacific Northwest experiment.

This component is geographically restricted to major urban centers in the Pacific Northwest, particularly the Willamette Valley of Oregon and the Puget Sound region in Washington, as well as the St. Helens seismic zone and the Pasco basin (fig. 18). The principle objective of this component is to revise existing assessments of earthquake hazards and risk in urban areas. Included in this objective are: the collection of seismic and geological data necessary to produce models of strong ground-motions and complete the earthquake history, the calculation of estimates of these 
strong ground-motions, estimation of expected ground failures, and deterministic and probabilistic estimation of risk. An updated catalog of all strong ground-motion monitoring sites in the Pacific Northwest should be prepared and kept current as the number of stations changes. The deployment of a free-field strong ground-motion network should be encouraged in the populated regions of the Pacific Northwest. The data from this network should be supplemented with building monitoring using a portable network.

Providing estimates of losses in urban regions from earthquakes and, if appropriate, from earthquake-induced landslides is also included in this component. Methods for obtaining inventories of buildings, lifelines, and transportation systems should be established. Strong ground shaking and ground failures would severly impact these

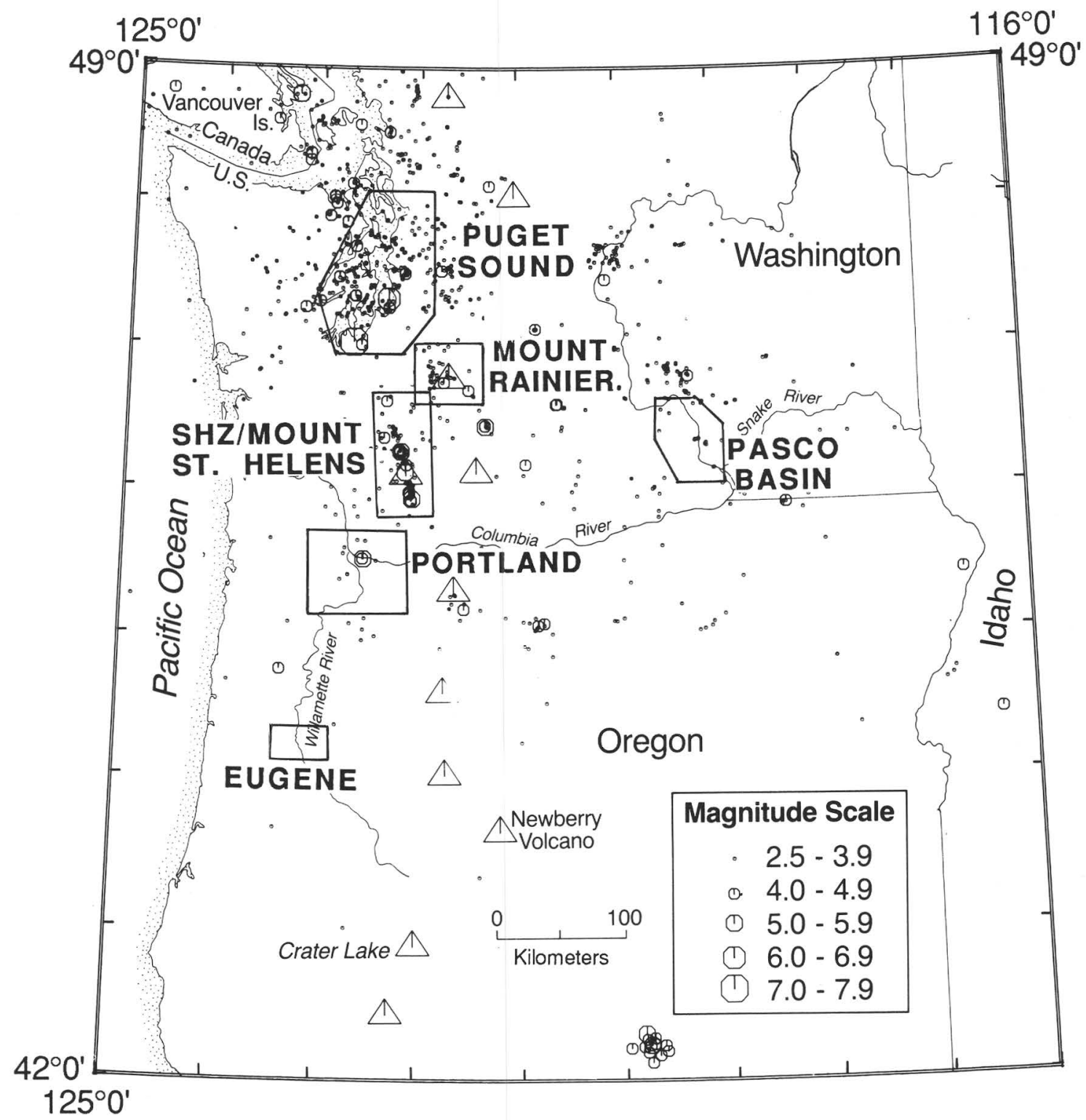

Figure 19. Map showing areas of special hazards or special studies. The Puget Sound, Portland, and Eugene urban areas are emphasized. Open triangles, Quaternary stratovolcanoes; open octagons, earthquake epicenter locations. The St. Helens zone (SHZ), Mount St. Helens, and Mount Rainier areas are identified hazards that require continued detailed monitoring and ongoing study. The degree of earthquake hazard in the Pasco basin is uncertain; however, considerable risk from earthquake shaking effects may exist for the people living in the area. 
facilities, which, generally, have not been designed to resist earthquakes.

Another objective of this component is to encourage the establishment and maintenance of systems to monitor and provide appropriate warnings to the population in areas where geologic hazards are particularly well-defined. For example, Mount St. Helens represents a clearly defined hazard that requires continued USGS monitoring and communication of results to the public. This objective should contribute to development of integrated computerbased information systems, mentioned previously. These systems must be designed to meet the needs of engineering and scientific users but should be flexible enough to allow nontechnical users to view typical end-product results. The data bases and display systems should be as machine independent as possible, considering existing technology and realistic considerations of funding.

A necessary cooperative project for this component is to complete an inventory of ground failure hazards in the Puget Sound and Willamette Valley areas. This inventory should be funded by the Landslide Program, but it should rely, as necessary, on cooperation from NEHRP scientists. This objective recognizes the need to produce comprehensive susceptiblity maps for ground failures of local origin within the study areas (such as landslides and liquefaction) as well as to investigate the hazards associated with large-volume rock slides and debris flows originating on Mount Rainier or other high-elevation areas outside of urban centers.

\section{Cooperative Hazard Mitigation Studies}

- Encourage implementation of earthquake-hazard mitigation measures.

- Encourage preparedness and response programs.

The fourth component of the USGS/NEHRP program in the Pacific Northwest must be the integration of research activities into preparedness, response, recovery, and mitigation activities. Scientific results must be communicated to the engineering and planning communities in formats that are understandable and usable. The primary responsibility of the USGS under this component of the program is to perform feasibility studies that will develop and (or) test methods for quantifying earthquake hazards and risks. Once a method is developed and (or) tested, it is necessary for the USGS to translate the results of these scientific studies into reports and onto maps so that the nature and extent of hazards and risks may be understood by nontechnical users. Then, end users (usually other Federal agencies, States, or municipalities) may decide what methods they wish to adopt for complete regional or local programs of implementation, preparedness, and mitigation. This element will require a new cooperative effort between the USGS and State agencies because many of the final products are best described, overseen, and checked by local scientists who are most capable of communicating with user groups in Oregon, Washington, and California. Working together, the USGS and representatives from Oregon, Washingtcn, and California will develop the pilot products each State cesires; methods of large-scale implementation will then be devised. We will try to convene a scientific oversight committee that includes knowledgeable USGS scientists who will be available to help evaluate locally directed work under this component. Projects under this component will be subject to peer review, but they will have different criteria than those used for the three scientific components.

Included in this component are meetings or workshops that focus on current science and issues in the Pacific Northwest. We include in this component meetings of scientists working under other components-this will provide State groups with the opportunity to be kept fully informed on the relatively rapid changes that are occurring in the scientific understanding of earthquake hazards of this region. These workshops should be jointly designed by the USGS and the States of Oregon, Washington, and California.

\section{Relation to the USGS Earthquake Hazards Reduction Program}

In November 1990, the USGS adopted a revised earthquake plan to guide agency investigations for fiscal years 1991 to 1995 . Scientific work under the new earthquake plan is organized around four goals: (I) understanding the earthquake source, (II) evaluating the earthquake potential, (III) predicting the effects of earthquakes, and (IV) utilizing research results. The four necessary components in our plan for the Pacific Northwest are, appropriately, subsets of the goals of the new national plan. Our components I and II largely span the objectives listed under goal II of the national plan, and our components III and IV are direct equivalents of goals III and IV of the national plan. The specific objectives of goal I of the national plan (determining the physical and mechanical behavior of active, crustal fault zones and developing quantitative models of the physics of the earthquake process) are not region specific.

\section{CONCLUSIONS}

A great subduction-zone earthquake that could devastate the Pacific Northwest is possible; crustal and intraplate earthquakes near population centers of the Pacific Northwest are probable. Either type of earthquake would severely impact the region. Loss of life could be high and damages could easily run into the billions of dollars. Thus, 
the principle scientific objectives of the USGS/NEHRP program in the Pacific Northwest are to establish estimates of the probabilities of the occurrences of crustal, intraplate, and great subduction-zone earthquakes and to establish estimates of the effects and damage due to each type of earthquake. Since earthquake hazards in the Pacific Northwest are both regional and local in scale, the earthquake hazard assessment program must be both regional and local in scale. The program must include: (1) regional and local monitoring of seismicity and deformation, (2) tectonic framework studies, (3) improved seismic hazard and risk assessments, and (4) cooperative hazard-mitigation studies.

The resulting scientific information will provide the foundation necessary for State governments, local governments, and the private sector to implement effective programs for earthquake hazard mitigation, preparedness, and response on regional and local scales.

\section{ACKNOWLEDGMENTS}

We are grateful to the U.S. Geological Survey Branch of Central Technical reports, in particular Rick Scott, for the outstanding preparation of this Circular on very short notice. We thank Randy Updike and Bob Schuster for their detailed reviews. We also thank Rob Wesson for providing the impetus for us to write this Circular.

\section{REFERENCES CITED}

Algermissen, S.T., Harding, S.T., Steinbrugge, L.V., and Cloud, W.K., 1965, The Puget Sound, Washington earthquake of April 29, 1965: U.S. Coast and Geodetic Survey, Preliminary Seismological and Engineering Reports, $26 \mathrm{p}$.

Ando, M., and Balazs, E.I., 1979, Geodetic evidence for aseismic subduction of the Juan de Fuca plate: Journal of Geophysical Research, v. 84, p. 3,023-3,028.

Atwater, B.F., 1987, Evidence for great Holocene earthquakes along the outer coast of Washington State: Science, v. 236, p. 942-944.

Baker, G.E., and Langston, C.A., 1987, Source parameters of the 1949 magnitude 7.1 south Puget Sound, Washington earthquake as determined from long-period body waves and strong ground motion: Bulletin of the Seismological Society of America, v. 77, p. 1,530-1,557.

Balsillie, J.H., and Benson, G.T., 1971, Evidence for the Portland Hills fault: Ore Bin, v. 33, p. 109-118.

Barnard, W.D., 1978, The Washington continental slope: Quaternary tectonics and sedimentation: Marine Geology, v. 27, p. 79-114.

Beck, M.E. and Engebretson, D.C., 1982, Paleomagnetism of small basalt exposures in the west Puget Sound area, Washington and speculations on the accretionary origin of the Olympic Mountains: Journal of Geophysical Research, v. 87, p. $3,755-3,760$.
Bucknam, R.C., and Barnhard, T.P., 1989, Evidence of sudden late Holocene uplift in the central Puget Lowland, Washington [abs.]: EOS, Transactions, American Geo’hysical Union, v. 70 , p. 1,332 .

Cady, W.M., 1975, Tectonic setting of the Tertiar' volcanic rocks of the Olympic Peninsula, Washington: Jou nal of Research of the U.S. Geological Survey, v. 3, p. 57:-582.

Cassidy, J.F., Ellis, R.M., and Rogers, G.C., 1988, The 1918 and 1957 Vancouver Island earthquakes: Pulletin of the Seismological Society of America, v. 78, F. 617-635.

Catchings, R.D., and Mooney, W.D., 1988, Crustal structure of the Columbia Plateau: Evidence for continental rifting: Journal of Geophysical Research, v. 93, p. 459-474.

Chleborad, A.F, and Schuster, R.L., 1989, Charac'eristics of slope failures induced by the April 13, 1949, and April 29, 1965, Puget Sound area, Washington, earthquake : U.S. Geological Survey Open-File Report 89-465, p. 106-113.

Cockerham, R.W., 1984, Evidence for a 180-km-long subducted slab beneath northern California: Bulletin of the Seismological Society of America, v. 74, p. 569-576.

Coffman, J.L., Von Hake, C.A., and Stover, C.W., eds., 1982, Earthquake history of the United States; revised edition: U.S. National Oceanic and Atmospheric AdministrationU.S. Geological Survey Publication 41-1, 270 p.

Cohee, B.P., Somerville, P.G., and Abrahamscn, N.A., 1991, Ground motions for hypothesized $\mathrm{Mw}=8$ subduction earthquakes in Washington and Oregon: Bulletin of the Seismological Society of America, v. 81, F 28-56.

Crandell, D.R., 1971, Postglacial lahars from Mount Rainier Volcano, Washington: U.S. Geological Sur'ey Professional Paper 677, $75 \mathrm{p}$.

Crosson, R.S., 1983, Review of seismicity in the Puget Sound region from 1970 through 1978: U.S. Gelogical Survey Open-File Report 83-19, p. 6-18.

DeMets, C., Gordon, R.G., Stein, S., and Argus D.F., 1987, A revised estmate of Pacific-North American motion and implications for western North America plate boundary zone tectonics: Geophysical Research Letters, v. 14, p. 911-914.

Drew, A.R., and Snay, R.A., 1989, DYNAP: Software for estimating crustal deformation from geodeti? data: Tectonophysics, v. 162, p. 331-343.

Ellsworth, W.L., in press, Earthquake history, 1769-1989, in Wallace, R.E., ed.: U. S. Geological Survey Professional Paper 1515.

EMSLAB Group, The EMSLAB electromagnetic sounding experiment, 1988: EOS, Transactions, American Geophysical Union, v. 69, p. 89-99.

Espinosa, A.F., Brockman, S.R., and Michael, J.A., 1986, Modified Mercalli Intensity distribution for the most significant earthquakes in Alaska, 18?9-1981: U.S. Geological Survey Open-File Report 86-203, 1 sheet.

Gower, H.D., Yount, J.C., and Crosson, R.S., 1985, Seismotectonic map of the Puget Sound region, Washington: U. S. Geological Survey Miscellaneous Investigations Series Map I-1613, scale 1:250,000.

Grant, W.C., Atwater, B.F., Carver, G.A., Darienz), M.E., Nelson, A.R., Peterson, C.D., and Vick, G.S., 1989, Radiocarbon dating of late Holocene coastal subsidence above the 
Cascadia subduction zone-compilation for Washington, Oregon, and northern California [abs.]: EOS, Transactions, American Geophysical Union, v. 70, p. 1,331.

Grant, W.C. and Weaver, C.S., in press, Seismicity of the Spirit Lake area: estimates of possible earthquake magnitudes for engineering design, in Schuster, R.L., and Meyer, W., eds., The formation and significance of major lakes impounded during the 1980 eruption of Mount St. Helens, Washington: U.S. Geological Survey Professional Paper.

Gutenberg, B. and Richter, C.F., 1954, Seismicity of the Earth (2d ed.): Princeton, New Jersey, Princeton University Press, $310 \mathrm{p}$.

Harding, S.T., Urban, T.C., and Diment, W.H., 1988, Evidence of recent tectonic deformation in the Puget Sound from seismic-reflection profiles [abs.]: EOS, Transactions, American Geophysical Union, v. 69, p. 1,314.

Hartzell, S.H. and Heaton, T.H., 1985, Teleseismic time functions for large shallow subduction zone earthquakes: Bulletin of the Seismological Society of America, v. 75, p. 965-1,004.

Heaton, T.H., and Hartzell, S.H., 1986, Source characteristics of hypothetical subduction earthquakes in the northwestern United States: Bulletin of the Seismological Society of America, v. 76, p. 675-703.

1989, Estimation of strong ground motions from hypothetical earthquakes on the Cascadia subduction zone, Pacific Northwest: PAGEOPH, v. 129, p. 131-201.

Heaton, T.H. and Kanamori, H., 1984, Seismic potential associated with subduction in the northwestern United States: Bulletin of the Seismologcial Society of America, v. 74, p. 933-941.

Hopper, M.G., Algermissen, S.T., Perkins, D.M., Brockman, S.R., and Arnold, E.P., 1982, The earthquake of December 14, 1872, in the Pacific Northwest [abs.]: Presented at the Seismological Society of America Annual Meeting, Anaheim, California, May, 1982.

Hopper, M.G., Langer, C.J., Spence, W.J., Rogers, A.M., Algermissen, S.T., 1975, A study of earthquake losses in the Puget Sound, Washington, area: U.S. Geological Survey Open-File Report 75-375, 298 p.

Idriss, I.M., and Seed, H.B., 1968, An analysis of ground motions during the 1957 San Francisco earthquake: Bulletin of the Seismological Society of America, v. 58, p. 2,013-2,032.

Keefer, D.K, 1983, Landslides, soil liquefaction, and related ground failures in Puget Sound earthquakes: U.S. Geological Survey Open-File Report 83-19, p. 280-299.

Kienle, C.F., Farooqui, S.M., Strazer, R.J., and Hamill, M.L., 1978, Investigation of the Ribbon Cliff landslide, Entiat, Washington: Shannon and Wilson, Inc., unpublished technical report, Seattle, Washington, $19 \mathrm{p}$.

Langston, C.A., 1981, A study of Puget Sound strong ground motion: Bulletin of the Seismological Society of America, v. 71, p. 883-903.

Lisowski, M., 1985, Geodetic strain measurements in central Vancouver Island: University of British Columbia, Vancouver, British Columbia, unpublished Master's thesis, 100 p.

Ludwin, R.S., Weaver, C.S., and Crosson, R.S., in press, Seismicity of Washington and Oregon, in Engdahl, E.R., ed., Neotectonics of North America: Geological Society of America, Boulder, Colorado.
Ma, L., 1988, Regional tectonic stress in western Washington from focal mechanisms of crustal and subcrustal earthruakes: University of Washington, Seattle, Washington, unpublished Master's thesis, 84 p.

Magill, J.R., Cox, A.V., and Duncan, R., 1981, Tillamook volcanic series: further evidence for tectonic rotation of the Oregon Coast Range: Journal of Geophysical Research, v. 86, p. 2,953-2,970.

Magill, J.R., Wells, R.E., Simpson, R.W., and Cox, A.V., 1982, Post $12 \mathrm{~m}$. y. rotation of southwest Washington: Journal of Geophysical Research, v. 87, p. 3,761-3,776.

Malone, S.D., and Bor, S., 1979, Attenuation patterns in the Pacific Northwest based on intensity data and the location of the 1872 north Cascades earthquake: Bulletin of the Seismological Society of America, v. 69, p. 531-546.

McPherson, B.C., 1989, Focal mechanisms and seismicity at the southern end of the Cascadia subduction zone [abs.]: Rocky Mountain Section of the Geological Society of America, Abstracts with Programs, 1989 Cordilleran Section, v. 21, p. 23.

Melosh, H.J., 1989, Stress and strain in the Cascadia subluction zone, [abs]: EOS, Transactions, American Geophysical Union, v. 70, p. 1,333.

Milne, W.G., 1956, Seismic activity in Canada west of th: 113th meridian, 1841-1951: Dominion Observatory Pub'ication 18, Ottawa, Canada, p. 126-127.

Misch, P., 1966, Tectonic evolution of the northern Casc?des of Washington State: Canadian Institute of Mining and Metallurgy, Special Report no. 8, p. 101-148.

Montessus de Ballore, F., comte de, 1906, Les Tremblements de Terre; Geographie Seismologique: Paris, A. Colin, 475 p.

Mooney, W.D., and Weaver, C.S., 1989, Regional crustal structure and tectonics of the Pacific coastal states; California, Oregon, and Washington, in Pakiser, L.C., and Mooney, W.D., eds., Geophysical Framework of the Continental United States: Geological Society of America, Eoulder, Colorado, p. 129-161.

Murphy, L.M. and Ulrich, F.P., 1951, United States Earthruakes, 1949: U.S. Coast and Geodetic Survey, Serial no. 745, 64 p.

Nelson, A.R., 1987, Apparent gradual rise in relative sea level on the south-central Oregon coast during the late Holcceneimplications for a great Cascadia earthquake hypothesis [abs.]: EOS, Transactions, American Geophysical Union, v. 68, p. 1,240 .

Noson, L.L., Qamar, A., and Thorsen, G.W., 1988, Washington State earthquake hazards: Washington Division of Geology and Earth Resources Information Circular, v. 85, 77 p.

Nuttli, O.W., 1952, The western Washington earthquake of April 13, 1949: Bulletin of the Seismological Society of America, v. 42, p. $21-28$.

Perkins, D.M., Thenhaus, P.C., Hanson, S.L., Ziony, J.I., and Algermissen, S.T., 1980, Probabilistic estimates of maximum seismic horizontal ground motion on rock in the Pacific Northwest and the adjacent continental shel ${ }^{f}$ : U. S. Geological Survey Open-File Report 80-471, 39 p.

Peterson, C.D., 1989, Megathrust and upper plate paleoseismicity of the southern Cascadia margin: U.S. Geological Survey Open-File Report 89-465, p. 33-34. 
Potter, C.J., Sanford, W.E., Yoos, T.R., Prussen, E.L., Keach, W., Oliver, J.E., Kaufman, S., and Brown, L.D., 1986, COCORP deep seismic reflection traverse of the interior of the North American cordillera, Washington and Idaho; implications for orogenic evolution: Tectonics, v. 5, p. 1,007-1,025.

Prescott, W.H. and Savage, J.C., 1984, Crustal deformation near Hanford, Washington: U.S. Geological Survey Open-File Report 84-797, 21 p.

Riddihough, R.P., 1977, A model for recent plate interactions off Canada's west coast: Canadian Journal of Earth Sciences, v. 14 , p. $384-396$.

Riddihough, R.P., 1984, Recent movements of the Juan de Fuca plate system: Journal of Geophysical Research, v. 89 , p. $6,980-6,994$.

Rogers, G.C., 1983a, Some comments on the seismicity of northern Puget Sound-southern Vancouver Island region: in U.S. Geological Survey Open-File Report 83-19, p. 19-39. 1983b, Seismotectonics of British Columbia: University of British Columbia, Vancouver, British Columbia, unpublished Ph.D. thesis, 227 p.

Rogers, G.C., and Hasegawa, H.S., 1978, A second look at the British Columbia earthquake of June 23, 1946: Bulletin of the Seismological Society of America, v. 68, p. 653-675.

Savage, J.C., Lisowski, M., and Prescott,W.H., 1981, Geodetic strain measurements in Washington: Journal of Geophysical Research, v. 86, p. 4,929-4,940.

Sbar, M.L., 1983, An explanation for contradictory geodetic strain and fault plane solution data in western North America: Geophysical Research Letters, v. 10, p. 177-180.

Schuster, R.L., 1983, Engineering aspects of the 1980 Mount St. Helens eruptions: Bulletin of the Association of Engineering Geology, v. 20, p. 125-143.

Shannon and Wilson, Inc., 1977, Geologic Studies in the 1872 earthquake epicentral region, in Washington Public Power Supply System: (WPPSS) Nuclear Projects Nos. $1 \& 4$, Preliminary Safety Analysis Report (unpublished), Amendment 23.

Shedlock, K.M., and Weaver, C.S., 1989, Rationale and outline of a program for earthquake hazards assessment in the Pacific Northwest: in U.S. Geological Survey Open-File Report 89-465, p. 2-10.

Snavely, P.D., Jr., 1988, Tertiary geologic framework, neotectonics, and petroleum potential of the OregonWashington continental margin, in Scholl, D.S., Grantz, A., and Vedder, J.G., eds., Geology and resource potential of the continental margin of western North America and adjacent ocean basins-Beaufort Sea to Baja California: Circum-Pacific Council on Energy Mineral Resources, Earth Science Series, v. 6, p. 305-335.

Somerville, P., Cohee, B., and Sen, M., 1989, Estimates of strong ground motions in the Seattle-Portland region from hypothesized magnitude 8 Cascadia subduction earthquakes: U.S. Geological Survey Open-File Report 89-465, p. 52-61.

Stanley, W.D., Mooney, W.D., and Fuis, G.S., 1990, Deep crustal structure of the Cascade Range and surrounding region from seismic refraction and magnetotelluric data: Journal of Geophysical Research, v. 95, p. 19,419-19,438.
Taber, J.J., and Smith, S.W., 1985, Seismicity and focal mechanisms associated with the subduction of the Juan de Fuca plate beneath Washington: Bulletin of the Seismological Society of America, v. 75, p. 237-249.

Tabor, R.W., 1972, Age of the Olympic metamorphism, Washington: K-Ar dating of low-grade metamorphic rocks: Bulletin of the Geological Society of America, v. 83, p. $1,805-1,816$.

Toppozada, T.R., Real, C.R., and Parke, D.L., 1981, Preparation of isoseismal maps and summaries of related effects of pre1900 California earthquakes: California D:vision of Mines and Geology Open-File Report 81-11, Sacramento, California, $182 \mathrm{p}$.

Ulrich, F.P., 1949, Reporting the northwest earthquake: Building Standards Monthly, June, 1949, reprinted ir Thorsen, G.W., compiler, 1986, The Puget Lowland eartlquakes of 1949 and 1965: Washington Division of Geological Earth Resources, Information Circular 81, p. 19-23.

U.S. Geological Survey, 1988, Probabilities of large earthquakes occurring in California on the San Andreas fault: U.S. Geological Survey Open-File Report 88-338, 62 p.

U.S. Geological Survey, 1990, Probabilities of large earthquakes in the San Francisco Bay region, California: U.S. Geological Survey Circular 1053, $51 \mathrm{p}$.

Uyeda, S., and Kanamori, H., 1979, Back-arc opening and the mode of subduction: Journal of Geophysical Research, v. 84 , p. 1,049-1,061.

Walter, S.R., 1986, Intermediate-focus earthquakes associated with Gorda plate subduction in northern California: Bulletin of the Seismological Society of America, v. 76, p. 583-588.

Weaver, C.S. and Baker, G.E., 1988, Geometry of the Juan de Fuca plate beneath Washington and northern Oregon from seismicity: Bulletin of the Seismologinal Society of America, v. 78, p. 264-275.

Weaver, C.S. and Malone, S.D., 1987, Overview of the tectonic setting and recent studies of eruptions of Mount St. Helens, Washington: Journal of Geophysical Research, v. 92, p. $10,149-10,154$.

Weaver, C.S., Norris, R.D., and Jonietiz-Trisler, C., 1990, Results of seismological monitoring in the Cascade Range, 1960-1989: earthquakes, eruptions, avalanches and other curiosities: Geoscience Canada, v. 17. p. 158-162.

Weaver, C.S. and Smith, S.W., 1983, Regional tectonic and earthquake hazard implications of a crustal fault zone in southwestern Washington: Journal of Geophysical Research, v. 88, p. 10,371-10,383.

West, D.O., 1989, Coastal terraces and subduction earthquakes: U.S. Geological Survey Open-File Peport 89-465, p. 36-37.

Weston Geophysical Research, Inc., 1976, The 1872 earthquake; significant data and conclusions, unp blished report prepared for United Engineers and Constructors, Inc.

Yelin, T.S., and Patton, H.J., 1991, Seismotectonics of the Portland, Oregon region: Bulletin of the Seismological Society of America, v. 81, p. 109-130.

Yount, J.C., 1983, Geologic units that likely control seismic ground shaking in the greater Seattle area: U.S. Geological Survey Open-File Report 83-19, p. 268-273. 


\section{APPENDIX—PACIFIC NORTHWEST SCIENCE PLAN WORKSHOP PARTICIPANTS}

The Office of Earthquake, Volcanoes, and Engineering of the U.S. Geological Survey initiated the process of formulating a broad science plan for the Pacific Northwest with a workshop in Golden, Colorado, on March 7 and 8, 1989. Although the results of that meeting have already been published elsewhere (Shedlock and Weaver, 1989), many of the ideas expressed there are included in this document. Participants in that workshop were:

- Algermissen, S.T. (U.S. Geological Survey)

- Bucknam, Robert C. (U.S. Geological Survey)

- Heaton, Thomas H. (U.S. Geological Survey)

- Lisowski, Michael (U.S. Geological Survey)
- Madole, Richard F. (U.S. Geological Survey)

- Muffler, L.J. Patrick (U.S. Geological Survey)

- Priest, George R. (Department of Geology and Mineral Industries, Oregon)

- Rogers, Garry C. (Geological Survey of Canad^)

- Schuster, Robert L. (U.S. Geological Survey)

- Shedlock, Kaye M. (U.S. Geological Survey)

- Stanley, William D. (U.S. Geological Survey)

- Tabor, Roland W. (U.S. Geological Survey)

- Updike, Randall G. (U.S. Geological Survey)

- Walsh, Timothy J. (Department of Natural Reso'irces, Washington) 





\section{SELECTED SERIES OF U.S. GEOLOGICAL SURVEY PUBLICATIONS}

\section{Periodicals}

Earthquakes \& Volcanoes (issued bimonthly).

Preliminary Determination of Epicenters (issued monthly).

\section{Technical Books and Reports}

Professional Papers are mainly comprehensive scientific reports of wide and lasting interest and importance to professional scientists and engineers. Included are reports on the results of resource studies and of topographic, hydrologic, and geologic investigations. They also include collections of related papers addressing different aspects of a single scientific topic.

Bulletins contain significant data and interpretations that are of lasting scientific interest but are generally more limited in scope or geographic coverage than Professional Papers. They include the results of resource studies and of geologic and topographic investigations; as well as collections of short papers related to a specific topic.

Water-Supply Papers are comprehensive reports that present significant interpretive results of hydrologic investigations of wide interest to professional geologists, hydrologists, and engineers. The series covers investigations in all phases of hydrology, including hydrogeology, availability of water, quality of water, and use of water.

Circulars present administrative information or important scientific information of wide popular interest in a format designed for distribution at no cost to the public. Information is usually of short-term interest.

Water-Resources Investigations Reports are papers of an interpretive nature made available to the public outside the formal USGS publications series. Copies are reproduced on request unlike formal USGS publications, and they are also available for public inspection at depositories indicated in USGS catalogs.

Open-File Reports include unpublished manuscript reports, maps, and other material that are made available for public consultation at depositories. They are a nonpermanent form of publication that may be cited in other publications as sources of information.

\section{Maps}

Geologic Quadrangle Maps are multicolor geologic maps on topographic bases in 7 1/2-or 15-minute quadrangle formats (scales mainly $1: 24,000$ or $1: 62,500$ ) showing bedrock, surficial, or engineering geology. Maps generally include brief texts; some maps include structure and columnar sections only.

Geophysical Investigations Maps are on topographic or planimetric bases at various scales; they show results of surveys using geophysical techniques, such as gravity, magnetic, seismic, or radioactivity, which reflect subsurface structures that are of economic or geologic significance. Many maps include correlations with the geology.

Miscellaneous Investigations Series Maps are on planimetric or topographic bases of regular and irregular areas at various scales; they present a wide variety of format and subject matter. The series also includes 7 1/2-minute quadrangle photogeologic maps on planimetric bases which show geology as interpreted from aerial photographs. Series also includes maps of Mars and the Moon.
Coal Investigations Maps are geologic maps on topographic or planimetric bases at various scales showing bedrock or surficial geology, stratigraphy, and structural relations in certain coal-resource areas.

Oil and Gas Investigations Charts show stratigraphic information for certain oil and gas fields and other areas having petroleum potential.

Miscellaneous Field Studies Maps are multicolor or black-andwhite maps on topographic or planimetric bases on quadrangle or irregular areas at various scales. Pre-1971 maps show bedrock geology in relation to specific mining or mineral-deposit problems; post-1971 maps are primarily black-and-white maps on various subjects such as environmental studies or wilderness mineral investigations.

Hydrologic Investigations A tlases are multicolored or black-andwhite maps on topographic or planimetric bases presenting a wide range of geohydrologic data of both regular and irregular areas; principal scale is $1: 24,000$ and regional studies are at $1: 250,000$ scale or smaller.

\section{Catalogs}

Permanent catalogs, as well as some others, giving comprehensive listings of U.S. Geological Survey publications are available under the conditions indicated below from the U.S. Geological Survey, Books and Open-File Reports Section, Federal Center, Box 25425, Denver, CO 80225. (See latest Price and Availability List.)

"Publications of the Geological Survey, 1879-1961" may be purchased by mail and over the counter in paperback book form and as a set of microfiche.

"Publications of the Geological Survey, 1962-1970" may be purchased by mail and over the counter in paperback book form and as a set of microfiche.

"Publications of the U.S. Geological Survey, 1971- 1981" may be purchased by mail and over the counter in paperback book form (two volumes, publications listing and index) and as a set of microfiche.

Supplements for $1982,1983,1984,1985,1986$, and for subsequent years since the last permanent catalog may be purchased by mail and over the counter in paperback book form.

State catalogs, "List of U.S. Geological Survey Geologic and Water-Supply Reports and Maps For (State)," may be purchased by mail and over the counter in paperback booklet form only

"Price and Availability List of U.S. Geological Survey Publications," issued annually, is available free of charge in paperback booklet form only.

Selected coples of a monthly catalog "New Publications of the U.S. Geological Survey" available free of charge by mail or may be obtained over the counter in paperback booklet form only. Those wishing a free subscription to the monthly catalog "New Publications of the U.S. Geological Survey" should write to the U.S. Geological Survey, 582 National Center, Reston, VA 22092.

Note.--Prices of Government publications listed in older catalogs, announcements, and publications may be incorrect. Therefore, the prices charged may differ from the prices in catalogs, announcements, and publications. 
